\title{
The Ancestral Caddo Ceramic Vessel and Vessel Sherd Assemblage from the Nawi haia ina Site (41RK170) in the Angelina River Basin, Rusk County, Texas
}

Timothy K. Perttula

Follow this and additional works at: https://scholarworks.sfasu.edu/ita

Part of the American Material Culture Commons, Archaeological Anthropology Commons, Environmental Studies Commons, Other American Studies Commons, Other Arts and Humanities Commons, Other History of Art, Architecture, and Archaeology Commons, and the United States History Commons

Tell us how this article helped you.

This Article is brought to you for free and open access by the Center for Regional Heritage Research at SFA ScholarWorks. It has been accepted for inclusion in Index of Texas Archaeology: Open Access Gray Literature from the Lone Star State by an authorized editor of SFA ScholarWorks. For more information, please contact cdsscholarworks@sfasu.edu. 
The Ancestral Caddo Ceramic Vessel and Vessel Sherd Assemblage from the Nawi haia ina Site (41RK170) in the Angelina River Basin, Rusk County, Texas

\section{Creative Commons License}

(c) (1) (8)

This work is licensed under a Creative Commons Attribution-NonCommercial 4.0 International License 


\title{
The Ancestral Caddo Ceramic Vessel and Vessel Sherd Assemblage from the Nawi haia ina Site (41RK170) in the Angelina River Basin, Rusk County, Texas
}

\author{
Timothy K. Perttula
}

\section{Introduction}

The Nawi haia ina site (41RK170), translated as "Our mother dwells below" (Mooney 1896:1096) in the Caddo language, contains habitation features and midden deposits from an ancestral Caddo residential occupation, as well as a small and spatially discrete cemetery (Perttula and Nelson 2003). These deposits date, based on the OxCal calibration of 11 C14 dates, between cal. A.D. 990-1190, A.D. 1185-1270, and A.D. 1297-1410 for the midden area and the Feature 2 burial, and between cal. A.D. 1432-1527 (see Selden and Perttula 2013) for the two investigated burials in the cemetery. The small cemetery appears to be contemporaneous as well as postdate the habitation deposits, and our excavations identified the extended burials of two adult Caddo women in reasonably good health. The excavations in the residential areas at the site documented a large midden, pit features, and post holes from one probable Caddo house, along with a large assemblage of utility ware and fine ware ceramics, the subject of this article. Also recovered were stemmed arrow points of Perdiz style and preforms, as well as expedient flake tools, and a smattering of lithic debris from tool manufacture. Faunal and floral remains indicate that the Caddo people here had a diverse diet that relied on deer, turtle, and small animals and birds, as well as maize, hickory, and walnut nuts. There was a heavy reliance on forest mast products, but the stable isotope analyses of the two adult burials indicates that maize comprised about 40-50 percent of the diet. These Caddo living, and buried, at the Nawi haia ina site, were part of a larger community living in the middle Sabine River basin.

The site lies on a low upland ridge immediately north of the confluence of Bromley and Shawnee creeks, about 366-368 feet amsl. Shawnee Creek is a southward-flowing tributary of the Angelina River, joining that stream about $14 \mathrm{~km}$ to the south of the Nawi haia ina site. This creek also originates along the Sabine River and Angelina River interfluve (Figure 1), ca. $8 \mathrm{~km}$ to the north. The Nawi haia ina site lies well within the modern and pre- $19^{\text {th }}$ century limits of the Pineywoods (Schmidly 2002).

The Nawi haia ina site was apparently first recorded by Jack T. Hughes, according to the site records on file at the Texas Archeological Research Laboratory, The University of Texas at Austin (TARL). It was among a list of sites Hughes recorded in his youth while spending "his spare time walking the fields and woods of North and East Texas" (Anonymous 2003:vii). There is almost no information available on the site - and the site number was assigned by TARL staff long after he visited it - other than a three-line note among a list of other Rusk County sites that read: "RU17. About 2 mis. S. of Henderson on N. bank of Shawnee Cr. \& W. side of Henderson-Laneville rd."

\section{Excavations}

The excavations (10 shovel tests, two $50 \times 50 \mathrm{~cm}$ units, and $181 \times 1 \mathrm{~m}$ units) at the Nawi haia ina site were concentrated in a midden deposit as well as in an area ca. $15 \mathrm{~m}$ to the east where ancestral Caddo burial features had been exposed in construction activities by the City of Henderson (Figure 2). The top of the midden had been scraped by machine, probably during previous construction activities, and then that exposed surface was recently buried by overburden from the current construction work. Underneath the midden is a yellowish-brown E-horizon soil. 


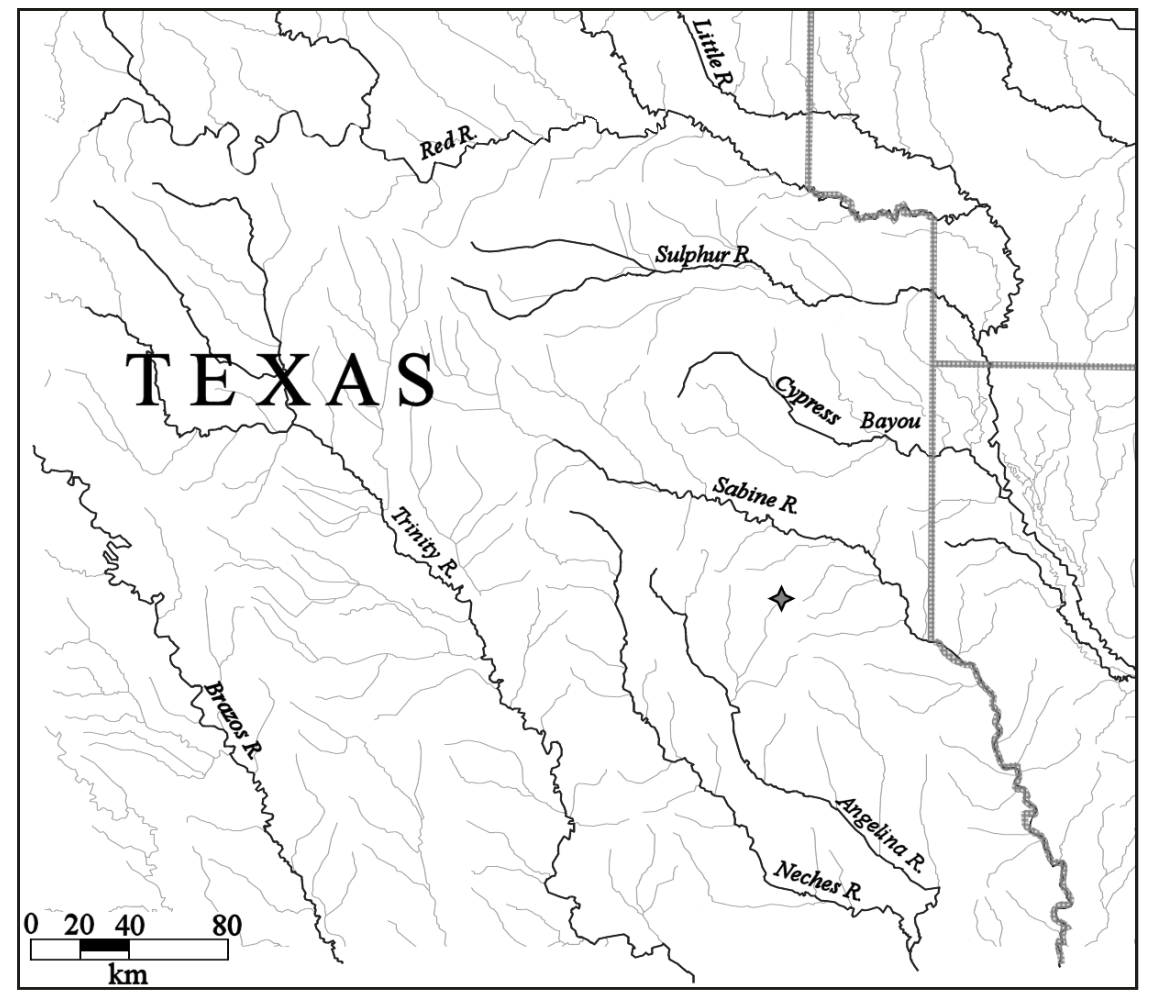

Figure 1. The location of the Nawi haia ina site in East Texas.

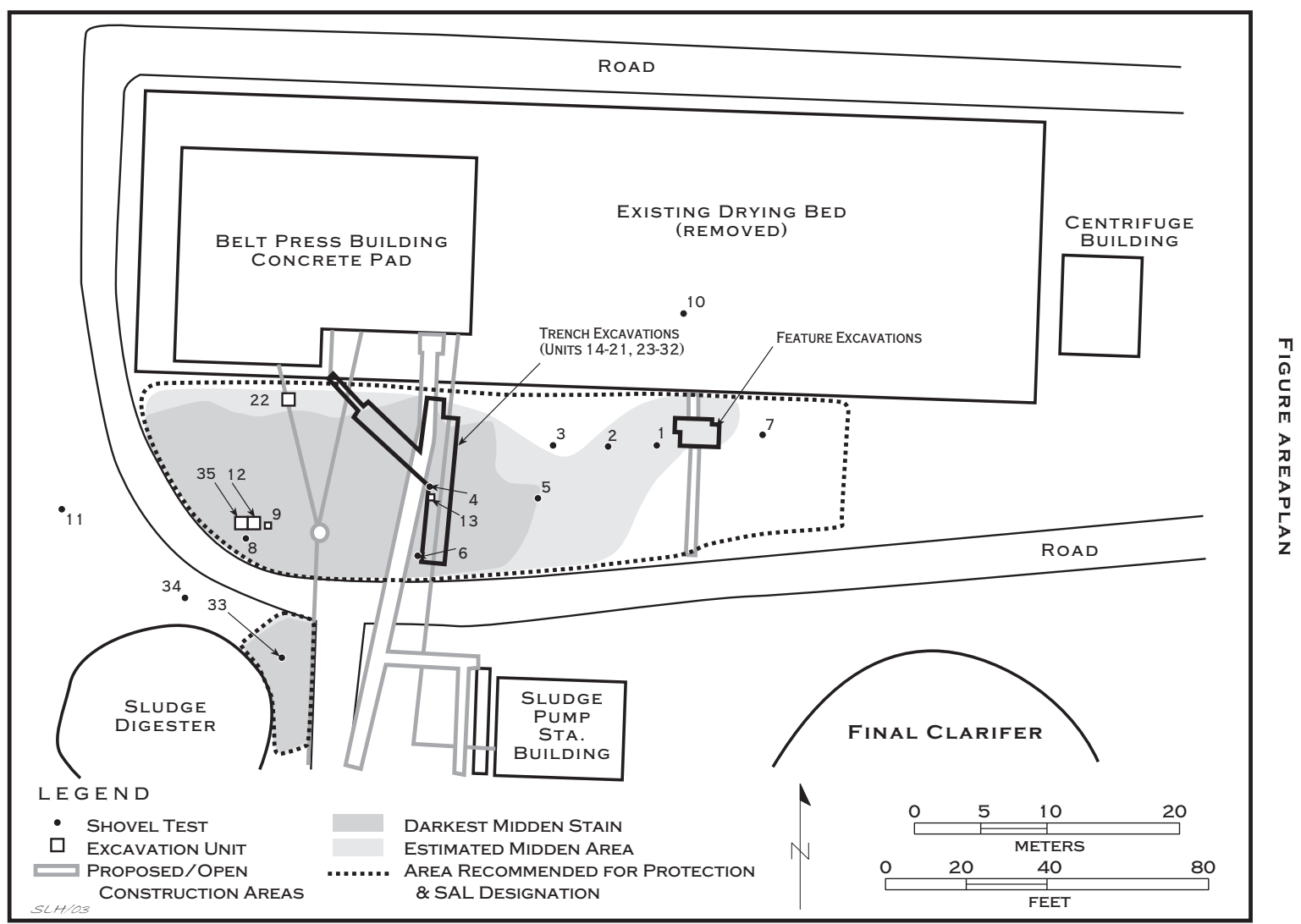

Figure 2. Excavation areas and development areas at the Nawi haia ina site. 
The first burial (Feature 1) is that of an ancestral Caddo adult female, in her mid-20s, apparently extended on her back, in a shallow grave pit, with her face looking to the northwest; the burial pit ran northwest-southeast (Figure 3). An engraved beaker (Vessel 1, Feature 1) had been placed along the right side of the head, but it had been badly damaged by the backhoe in construction activities, as had the skull and other parts of the body. In clearing dirt that had washed in the trench subsequent to the burial first being exposed, a second pottery vessel (a plain bowl, Feature 1, Vessel 2) was discovered hanging out of the trench wall.

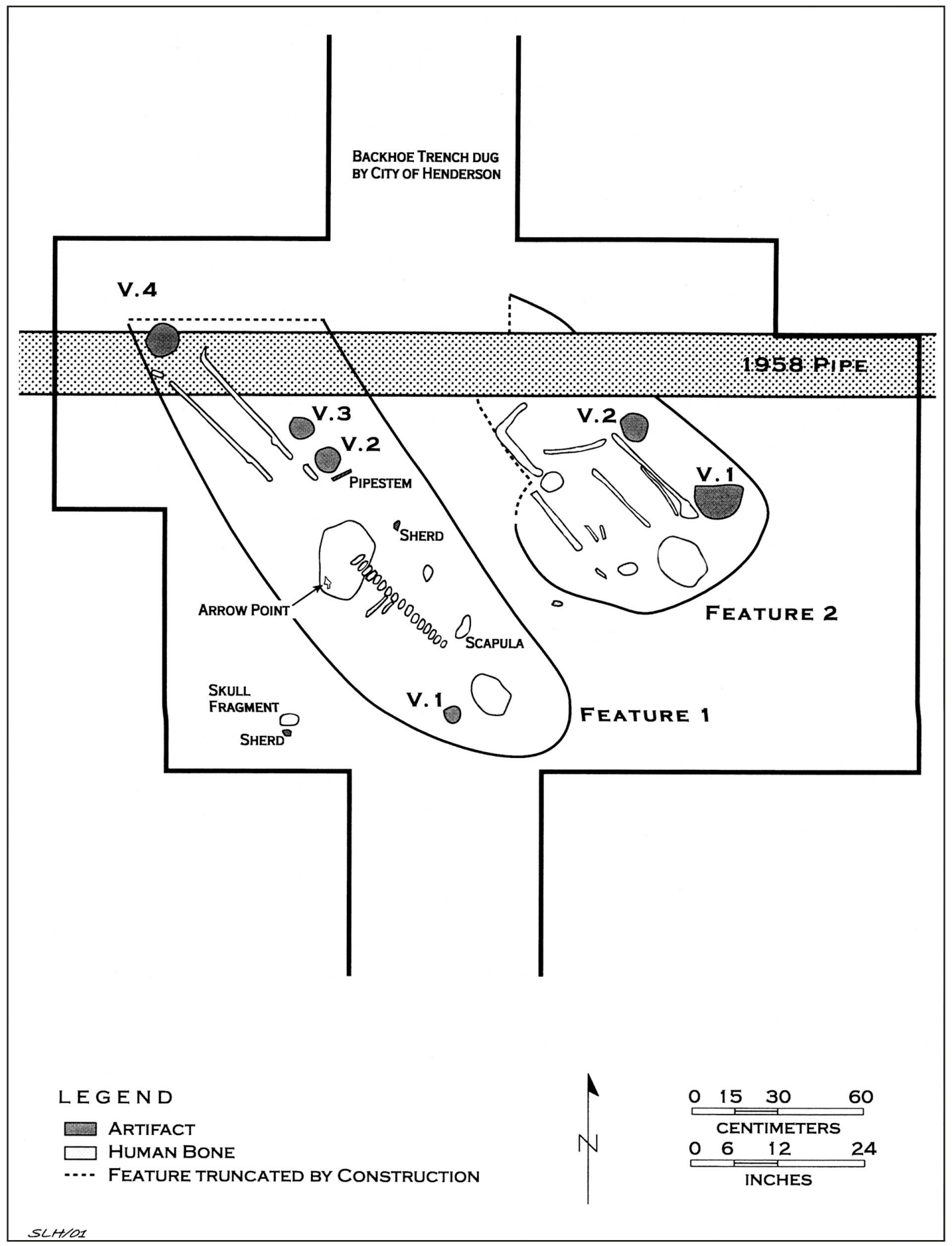

Figure 3. Plan of Feature 1 and 2 Excavations at the Nawi haia ina site (41RK170). 
With the permission of the Caddo Nation of Oklahoma, a sample of left and right rib fragments (14.4 g) from the Feature 1 burial were submitted to Beta Analytic for a radiocarbon assay and stable isotope (C13/C12) analysis. The conventional radiocarbon age of the remains is $400 \pm 40$ years before present (B.P.), with a $13 \mathrm{C} / 12 \mathrm{C}$ ratio of $-15.4 \mathrm{o} / \mathrm{oo}$ (Beta-164352). The 2 sigma calibrated age range of the human remains is A.D. 1432-1527. These results indicate there is a 95 percent chance that the adult Caddo female died and was buried sometime in the middle part of the $15^{\text {th }}$ century to the early part of the $16^{\text {th }}$ century, at least one generation after the midden was deposited elsewhere on the Nawi haia ina site.

In addition to the human remains in Feature 1, several funerary objects had been placed in the burial pit to accompany the deceased to the afterlife (because the burial had been disturbed in the past, there may have been additional funerary objects - now displaced or destroyed-placed with the burial beyond those documented here). This includes portions of four ceramic vessels, a clay pipe stem, and a single arrow point.

Feature 2 is about $15 \mathrm{~cm}$ east of Feature 1 (see Figure 3). It was first noted because of an exposed long bone in the eastern wall of the recently excavated City of Henderson backhoe trench. The feature had also been damaged by the excavation of a pipeline in 1958, and the pipe crossed over the mid-section of the burial feature. A profile of the backhoe trench area along the western side of the burial indicated that the burial pit was dug into prehistoric midden deposits and extended into the underlying E-horizon, and a dark brown midden fill comprised the burial pit itself.

Although the overall length of the Feature 2 burial pit when it was dug by the ancestral Caddo is unknown (see Figure 3), the width of the pit $(65 \mathrm{~cm})$, and the human remains placed in the burial indicate that the individual buried here was an adult Caddo. Diane E. Wilson (2003) identified the Feature 2 burial as that of an adult female, approximately 35-39 years of age. The human remains are not as well preserved as the remains in Feature 1, and this may be due to the shallow placement of the burial itself below the ground, differences in the organic content of the burial fills, and perhaps also the effects of modern construction activities.

A sample $(13.0 \mathrm{~g})$ of left femur fragments from Feature 2 was submitted for a radiocarbon assay and stable carbon isotope analyses. The conventional radiocarbon age is $580 \pm 40$ B.P., with a $13 \mathrm{C} / 12 \mathrm{C}$ ratio of $-15.3 \mathrm{o} / \mathrm{oo}$ (Beta-164353). The two sigma age range is cal. A.D. 1300-1420. From these age ranges, it is apparent that the Feature 2 burial is older-by a generation or two-than the Feature 1 burial, but contemporaneous with the latest midden deposits. The adult female in the Feature 2 burial pit died sometime in the $14^{\text {th }}$ century to very early $15^{\text {th }}$ century.

Portions of two pottery vessels were placed in the Feature 2 burial pit (see Figure 3). Vessel 1 was placed by the right shoulder, and Vessel 2 was near the right hip. As with Feature 1, there may have been other funerary objects placed with the burial at the time of interment, but if so, they would have been removed when the Caddo burial was damaged by modern construction activities.

\section{Age of the Archaeological Deposits}

In addition to the two radiocarbon assays obtained on human remains from the two ancestral Caddo adult burials in Feature 1 and 2, another 10 samples were submitted to Beta Analytic, Inc. on charred plant remains (hickory nutshells and charred maize cupules and cob fragments) from several features and midden contexts in the midden area excavations. Key information on these samples is presented in Table 1. 
Table 1. Radiocarbon samples from the Nawi haia ina site (41RK170).

\begin{tabular}{|c|c|c|c|c|c|c|}
\hline Lab No. & Context & Material & $\begin{array}{l}\text { Conventional } \\
\text { Radiocarbon } \\
\text { age (years B.P.) }\end{array}$ & $\begin{array}{l}\text { Calibrated } \\
\text { Intercept }\end{array}$ & $\begin{array}{l}1 \text { Sigma } \\
\text { age range }\end{array}$ & $\begin{array}{l}2 \text { Sigma } \\
\text { age range }\end{array}$ \\
\hline \multicolumn{7}{|c|}{ Woodland Period } \\
\hline B-166761 & F. 4 & $\begin{array}{l}\mathrm{NS} \\
1.2 \mathrm{~g}\end{array}$ & $2130 \pm 40$ & 170 B.C. & 200-100 B.C. & $\begin{array}{l}\text { 350-300 B.C. } \\
\text { 220-50 B.C. }\end{array}$ \\
\hline \multicolumn{7}{|c|}{ Ancestral Caddo, Group 1} \\
\hline B-166767 & $\begin{array}{l}\mathrm{U} 27, \\
30-50 \mathrm{~cm}\end{array}$ & $\begin{array}{l}\mathrm{NS} \\
4.6 \mathrm{~g}\end{array}$ & $960 \pm 50$ & A.D. 1030 & A.D. $1020-1160$ & A.D. $990-1190$ \\
\hline \multicolumn{7}{|c|}{ Ancestral Caddo, Group 2} \\
\hline B-166764 & F. 19 & $\begin{array}{l}\text { Carya } \\
\text { Wood, } \\
1.6 \mathrm{~g}\end{array}$ & $840 \pm 90$ & A.D. 1210 & $\begin{array}{l}\text { A.D. } 1050-1100 \\
\text { A.D. } 1140-1270\end{array}$ & A.D. $1010-1300$ \\
\hline B-166770 & $\begin{array}{l}\mathrm{U} 30, \\
20-40 \mathrm{~cm}\end{array}$ & $\begin{array}{l}\mathrm{NS}, \\
4.6 \mathrm{~g}\end{array}$ & $880 \pm 60$ & A.D. 1180 & A.D. $1040-1230$ & A.D. $1020-1270$ \\
\hline B-166765 & $\begin{array}{l}\mathrm{U} 19, \\
10-30 \mathrm{~cm}\end{array}$ & $\begin{array}{l}\mathrm{NS}, \\
3.3 \mathrm{~g}\end{array}$ & $840 \pm 60$ & A.D. 1210 & A.D. $1160-1260$ & A.D. $1030-1280$ \\
\hline B-166762 & F. 18 & $\begin{array}{l}\mathrm{NS}, \\
2.1 \mathrm{~g}\end{array}$ & $840 \pm 40$ & A.D. 1210 & A.D. $1180-1250$ & $\begin{array}{l}\text { A.D. } 1150-1270 \\
\text { A.D. } 1060-1080\end{array}$ \\
\hline \multicolumn{7}{|c|}{ Ancestral Caddo, Group 3} \\
\hline B-166769 & $\begin{array}{l}\mathrm{U} 31, \\
20-40 \mathrm{~cm}\end{array}$ & $\begin{array}{l}\mathrm{NS}, \\
2.6 \mathrm{~g}\end{array}$ & $690 \pm 70$ & AD 1290 & $\begin{array}{l}\text { A.D. } 1270-1310 \\
\text { A.D. } 1360-1390\end{array}$ & A.D. $1220-1410$ \\
\hline B-166768 & $\begin{array}{l}\mathrm{U} 28, \\
30-40 \mathrm{~cm}\end{array}$ & $\begin{array}{l}\mathrm{NS} \\
4.1 \mathrm{~g}\end{array}$ & $660 \pm 70$ & AD 1300 & A.D. $1280-1400$ & A.D. $1250-1420$ \\
\hline B-166763 & F. 22 & $\begin{array}{l}\text { corn } \\
\text { cupules, } \\
1.7 \mathrm{~g}\end{array}$ & $630 \pm 80$ & $\begin{array}{l}\text { A.D. } 1310,1370 \\
\text { A.D. } 1380\end{array}$ & A.D. $1290-1410$ & A.D. $1260-1430$ \\
\hline B-166766 & $\begin{array}{l}\mathrm{U} 20, \\
10-20 \mathrm{~cm}\end{array}$ & $\begin{array}{l}\mathrm{NS}, \\
4.0 \mathrm{~g}\end{array}$ & $620 \pm 60$ & $\begin{array}{l}\text { A.D. } 1310,1360 \\
\text { A.D. } 1390\end{array}$ & A.D. $1290-1410$ & A.D. $1280-1420$ \\
\hline
\end{tabular}

NS=charred hickory nutshells

The calibrated ages from the charred plant remain samples in midden deposits and features at the Nawi haia ina site fall readily into four groups. The first group (see Table 1) is the 220-50 B.C. and 300-350 B.C. age ranges from charred nutshells in Feature 4, which indicates that the sample of charred hickory nutshells in this feature is associated with the early Woodland period occupation of the site. The feature itself, a shallow pit, is interpreted as being associated contextually with the underlying Woodland period archaeological deposits in the E-horizon sediments. 
The second group is the one calibrated date from $30-50 \mathrm{~cm}$ bs in Unit 27 that has a two sigma age range of A.D. 990-1190 (see Table 1). At two sigma, however, the age range does overlap very slightly with four other calibrated dates (the third group of dates) that range from as a group A.D. 1185-1270 (see Selden and Perttula 2013). Thus, there is a possibility that the Beta-166767 calibrated date simply represents the earliest end of an ancestral Caddo occupation in the midden area that began in the late $12^{\text {th }}$ century.

The third group of calibrated radiocarbon samples include Beta-166762, 166764, 166765, and 166770. At two sigma age ranges, these calibrated ages are from Caddo midden and feature contexts at the Nawi haia ina site that range from A.D. 1185-1270 (see Table 1).

The fourth and final group of calibrated radiocarbon samples are Beta-166763, 166766, 166768, and 166769. At two sigma (95 percent probability), the age ranges of these dates fall between cal. A.D. 12971410. These calibrated dates may represent a consecutive series of age ranges from an archaeological deposit that was periodically accumulating as midden debris and ashy midden over parts of several centuries.

Regardless of the way we partition and/or group the second, third, and fourth calibrated radiocarbon samples from the Nawi haia ina site, the most likely interpretation of the radiocarbon ages altogether is that the site was occupied-albeit not continuously-between ca. A.D. 1185-1410 by Caddo peoples. Peaks in occupation may have occurred early in the $13^{\text {th }}$ century and then again in the $14^{\text {th }}$-early $15^{\text {th }}$ century, during the accumulation of Zone II and III midden deposits.

The vertical position of the radiocarbon samples from general midden levels roughly sort in stratigraphic order, if we exclude the calibrated dates on nutshell from $30-40 \mathrm{~cm}$ in Units 28 and 31 (see Table 1). Without those two dates, the vertical arrangement of the remaining calibrated samples is as follows, using the calibrated intercepts for simplicity's sake:
$15 \mathrm{~cm}$ (mid-point of $10-20 \mathrm{~cm} \mathrm{bs})$
A.D. $1310,1360,1390$
$20 \mathrm{~cm}$ (mid-point of $10-30 \mathrm{~cm}$ bs)
A.D. 1210
$30 \mathrm{~cm}$ (mid-point of $20-40 \mathrm{~cm} \mathrm{bs})$
A.D. 1180
$40 \mathrm{~cm}$ (mid-point of $30-50 \mathrm{~cm}$ bs)
A.D. 1030

The two sigma age ranges for the same samples are:
$15 \mathrm{~cm}$ (mid-point of $10-20 \mathrm{~cm}$ bs)
A.D. $1280-1420$
$20 \mathrm{~cm}$ (mid-point of $10-30 \mathrm{~cm} \mathrm{bs}$ )
A.D. $1030-1280$
$30 \mathrm{~cm}$ (mid-point of $20-40 \mathrm{~cm}$ bs)
A.D. $1020-1270$
$40 \mathrm{~cm}$ (mid-point of 30-50 cm bs)
A.D. $990-1190$

From these data, it is possible to suggest that the midden deposits at the site may have accumulated (albeit slowly) in a stratified manner over several hundred years. Given the limits of the present sample of calibrated dates from midden and feature contexts, the various samples do demonstrate that these archaeological deposits accumulated by the early part of the $15^{\text {th }}$ century. As such, they basically predate Feature 1. The calibrated two sigma age range of this Caddo burial is A.D. 1432-1527.

\section{Clay Artifacts}

The clay artifacts are dominated by ceramic vessel sherds from fine wares and utility ware vessels that were used, broken, and discarded in the midden deposits. In the burial area, the vessels and vessel fragments placed with the two adult female Caddos are dominated by fine wares or plain wares, particularly engraved bowls and carinated bowls. Other ceramic artifacts include pipes, miscellaneous clay objects, and pieces of burned clay and daub. 


\section{Vessels in Features 1 and 2, and Ceramic Pipe Sherd in Feature 1}

Vessel 1 in Feature 1 was placed along the left side of the head. It is the lower portions (base and lower body) of an engraved beaker (Figure 4a-b); the upper portions were removed when it was apparently hit by the backhoe trench excavated by the City of Henderson. The vessel, chocolatecolored on the exterior surface and unsmoothed on the vessel interior, has been well-burnished on the exterior, including the base; the base is fire-clouded. The beaker was fired in a reducing environment, but cooled in the open air (see Teltser 1993:Figure 2f). Beaker body walls are $6.2 \mathrm{~mm}$ thick, and the flat base is $6.7 \mathrm{~mm}$ in thickness. Near the base, the beaker is $8.5 \mathrm{~cm}$ in diameter.

The Feature 1, Vessel 1 engraved decoration consists of two vertically-set lines that created vertical panels (probably four panels) around the beaker. Within the panels are curvilinear and circular elements of cross-hatched scrolls; the lowermost part of the vessel body is encircled with a single horizontal engraved line (see Figure 4). A red hematite-rich clay pigment was smeared in the engraved lines.

Similar decorated beakers have been found in the Sabine, Angelina, and Neches river basins in East Texas in Early to Middle Caddo period contexts (Rogers and Perttula 2004; Suhm and Jelks 1962:Plate 61c; Walters 1997:Figure 2; Walters et al. 1998:Figures 11a, 13b, and 14d). This includes roughly contemporaneous Caddo sites in Smith, Rusk, and Panola counties, among them the Oak Hill Village (41RK214), Redwine (41SM193), and Langford (41SM197), as well as the W. B. Stillwell (41PN15) site and 41RK79; in the case of the latter site, the beaker was decorated with a curvilinear incised-punctated motif rather than having the more common engraved designs.

Two vessels (Vessels 2 and 3) were placed along the right side of the body in the area of the knee and upper leg. Vessel 2 is a shallow and plain conical bowl, apparently about 95 percent complete. This vessel in Feature 1 is $11.9 \mathrm{~cm}$ in diameter and stands $4.5 \mathrm{~cm}$ in height. The rim and body walls are about 6.0 $\mathrm{mm}$ thick, and the rim is direct with a flat lip. The reddish-brown vessel has been well-burnished on both interior and exterior vessel surfaces, including the base, and there is a fire-cloud on the exterior base and lower vessel body. The vessel has a clay and iron-rich paste that was tempered with grog; there are charred organics remaining in the paste, and Vessel 2 was fired in a reducing environment, but then cooled in the open air, leaving the vessel core a dark color, but the exterior vessel surface is a light reddish-brown color.

Vessel 3 is a carinated bowl with a very distinctive negative engraved scroll motif (Figure 5). About 50 percent of this vessel is present. The Vessel 3 engraved motif on the rim consists of a series (at least five are represented on the rim section, but there were probably 10 to 12 such decorative elements repeated around the rim) of deeply engraved rectilinear and circular designs between horizontal engraved lines below the lip and encircling the base of the rim carination (Figure 5). These decorative elements have created a series of short negative scrolls between the repeated engraved rectilinear and circular series.

This vessel has a direct rim with a flat and slightly exterior-folded lip. The rim and upper body on the exterior vessel surface has been burnished, but the base has been scraped and partially smoothed. On the interior, the rim and body have been smoothed, while the base is rough and only poorly smoothed. It 


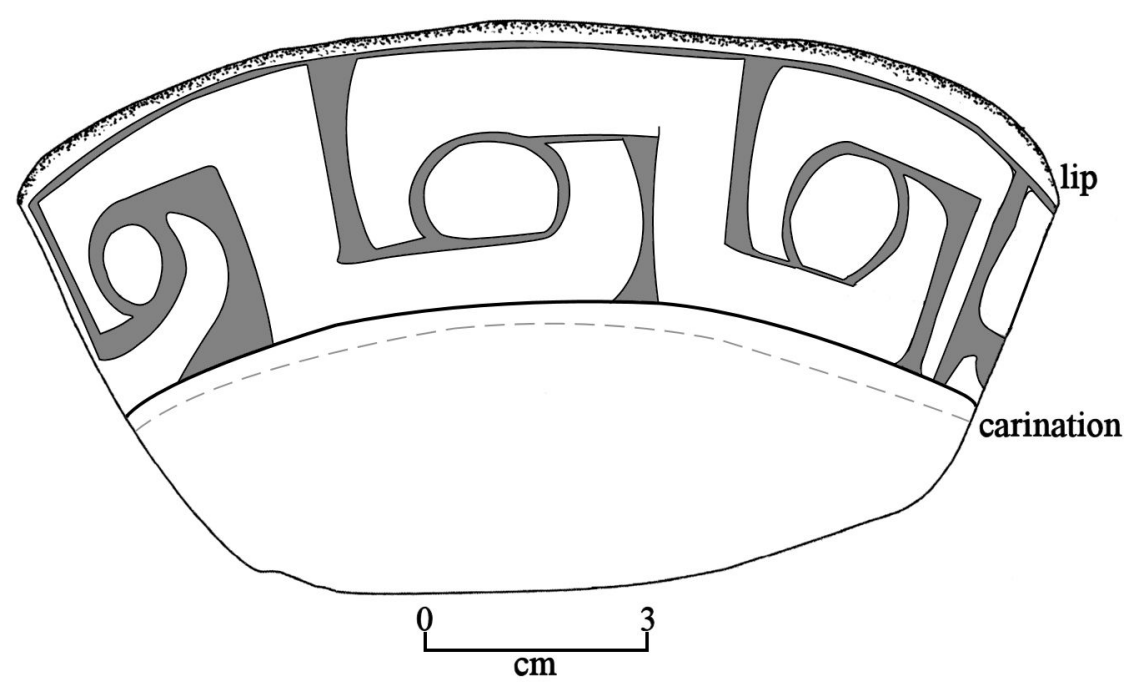

Figure 5. Decorative elements on Feature 1, Vessel 3.

has a clay paste tempered with grog, and Vessel 3 was fired in a reducing environment, then subsequently cooled in the open air; pieces of charred organics are visible in the paste. It has a deep dark brown surface color. The vessel stands $4.6 \mathrm{~cm}$ in height and has a $13.6 \mathrm{~cm}$ orifice diameter. At the rim, the vessel walls are $5.9 \mathrm{~mm}$ thick; the flat base is only $6.8 \mathrm{~mm}$ in thickness.

Vessel 4 had been placed near the feet (see Figure 3). What remained is about 30 percent of a plain and heavily smudged/sooted carinated bowl with a flaring rim. This vessel has been smoothed on the exterior surface, but the interior surface is pitted and scratched on the base and body walls. The sooting/ smudging is present on both the interior and exterior basal surface as well as a portion of the exterior rim and upper body. It has a sandy paste, and has been tempered with grog; there are also charred organics in the paste, suggesting the vessel was not fired long enough to burn up any incidental organics included in the vessel paste.

Vessel 4 stands only $4.1 \mathrm{~cm}$ in height, with an estimated $9.0 \mathrm{~cm}$ orifice diameter. It has a short and everted rim with a rounded lip; rim thickness is $5.4 \mathrm{~mm}$. Body and base walls are $5.5 \mathrm{~mm}$ and $6.2 \mathrm{~mm}$, respectively.

A long-stemmed Red River pipe sherd (generally manufactured by the Caddo in northeastern Texas between ca. A.D. 900-1400, see Hoffman 1967) was placed just to the southeast of Vessel 2 (see Figure 3 ). The calibrated radiocarbon assay on the Feature 1 remains suggests that this pipe sherd may not have been a deliberate grave offering, but became incorporated in the burial fill, which was primarily composed of midden deposits. The remaining pipe sherd is about $65.0 \mathrm{~mm}$ in length, and it was broken at the attachment of the stem and bowl; it is likely that the remainder of the stem and pipe bowl had been removed during previous construction activities. The pipe stem has been tempered with bone and grog, and the pipe was fired in a reducing or low oxygen environment. At the mouth, the stem diameter is 12.5 $\mathrm{mm}$, widening to $14.8 \mathrm{~mm}$ in diameter at the base of the bowl orifice. Interior stem diameters range from 3.4 to $3.6 \mathrm{~mm}$.

Vessel 1 in Feature 2 is a plain carinated bowl that stood at least $10 \mathrm{~cm}$ in height. It had been cut in half by the 1958 pipeline trench. When reconstructed, a little bit more than 50 percent of Vessel 1 from Feature 2 remains, and the broken edges are angular, with evidence of machine marks on the interior body and base. The carinated bowl has a deep rim, and the vessel stands $10.5 \mathrm{~cm}$ in height; the orifice diameter is estimated at $21.5 \mathrm{~cm}$. It has been smoothed on both interior and exterior surfaces, but there 
are small pock-marks and pitted areas on the interior rim surface and body as well as the exterior rim. There are fire clouds on the interior rim and base and most of the exterior basal surface. Vessel 1 has been tempered with grog, and it has a clay paste. Examination of the vessel core indicates that it was fired in a reducing environment, but cooled in the open air, leaving the vessel a light brown color on both the interior and exterior surfaces (see Teltser 1993:Figure 2f). The flat base is $11.2 \mathrm{~mm}$ thick, while the rim and body walls are $8.4 \mathrm{~mm}$ to $9.4 \mathrm{~mm}$, respectively.

Vessel 2 in Feature 2 was represented by sherds from the base and lower body of a moderately-size vessel, based on the $9.5 \mathrm{~cm}$ diameter of the reconstructed base; the remainder of the vessel had been destroyed during the excavation of the pipeline trench. The base is $10.6 \mathrm{~mm}$ thick, and the lower vessel body walls are $9.7 \mathrm{~mm}$ in thickness. The vessel fragment has been burnished on its exterior surfacewhich is a reddish-brown color-with fire-clouding on both interior and exterior surfaces, and the small bit of lower body is undecorated. The exterior base is well-pitted and scratched from use, and there are several small pits on the interior base surface. Vessel 2 has a sandy paste and was tempered with grog. Inspection of the vessel sherd core indicates that it was fired in a reducing environment, and then pulled from the fire to cool in the open air (see Teltser 1993:Figure 2f).

Found in association with Vessel 2 are three small sherds from another vessel; their small size suggests they are incidental inclusions in the burial fill. These sherds are from a burnished bowl or carinated bowl (7.0 mm wall thickness) that has part of an undetermined engraved motif. The motif appears to be comprised of at least two widely-spaced curvilinear lines, the second of which has a series of engraved lines forming a series of ovals. None of the engraved sherds from the midden excavations have similar decorative elements, although several have series of curvilinear engraved lines with either circular or rectilinear elements. The sherds are from a grog-tempered vessel fired in a reducing environment, but cooled in a high oxygen environment.

A small ( $22 \times 25 \mathrm{~m}$ in length and width) and very thin $(2.7 \mathrm{~mm})$ marine shell pendant was found on the surface after a heavy rain, just to the east of the Feature 1 and 2 excavations (Perttula and Nelson 2003:Figure 2.21). The pendant has two suspension holes at one end (each about $2.4 \mathrm{~mm}$ in diameter), and eight equally-spaced notches around the circumference on one side of the ornament. Its proximity to the Feature 1 and 2 burials, although found in back dirt - and the rarity of shell ornaments, particularly a marine shell ornament that would have come from the Texas Gulf coast, in other than Caddo burial contexts - suggests that this pendant had been displaced from a burial feature at the site, but not necessarily displaced from Feature 1 or 2.

\section{Ceramic Vessel Sherds}

Analysis of the ceramics from the Nawi haia ina site is based on differences in paste and temper, type of sherd (i.e., rim, body, or base), rim and lip form (cf. Brown 1996:Figure 2-12), decoration (if present), surface treatment (smoothing, burnishing, or polishing; see Rice 1987), and oxidation patterns (cf. Teltser 1993). Sherd cross-sections were inspected macroscopically and with a 10X hand lens to determine the character of the paste and its inclusions. Determining the firing atmosphere - the conditions of temperature, duration of firing, clays with different organic contents, or the amount of oxygen available at the time of firing - is based on the identification of the firing core in the sherd cross-sections and the identification of oxidation patterns as defined in Teltser (1993:535-536 and Figure 2).

More specifically, the following attributes were employed in the analysis of the ceramics from the Nawi haia ina site: (a) temper: the deliberate and indeterminate materials found in the paste (Rice 1987:411), including a variety of tempers (grog or crushed sherds, bone, hematite, and quartz sands, etc.) and "particulate matter of some size"; (b) although most of the sherds have indeterminate vessel forms, where sherds were large enough, vessel form categories noted include open containers (bowls, carinated bowls, and compound bowls) and restricted containers, including jars and bottles. As restricted 
containers, jars allow access by hand, but bottles do not (Brown 1996:335). Other form attributes include rim profile (outflaring or everted, vertical or standing, and inverted), lip profile (rolled to the exterior, rounded, flat, or thinned), and base shape (flat or rounded); (c), core colors: observations on ceramic crosssection colors permit consideration of oxidation patterns (Teltser 1993:Figure 2), and thus the conditions under which the vessel was fired and then cooled after firing. Also noted is the presence and location of fireclouding, sooting or smudging from cooking use (Skibo 1992), and charred organic remains. Finally, wall thickness was recorded in millimeters (mm), using a vernier caliper, along the mid-section of the sherd.

With respect to interior and exterior surface treatment, the primary methods of finishing the surface of the vessel included smoothing, burnishing, and polishing (Rice 1987:138), although a few sherds still have scraping marks from initial surface treatment activities; brushing, while a popular method of roughening the surface (particularly the body of large and small Middle and Late Caddo period cooking jars in the Neches/Angelina and Sabine river basins) with stiff bundles of grasses (e.g., Cliff and Perttula 2002; Fields 1995; Middlebrook 1994; Perttula 2013; Rogers and Perttula 2004), is considered a decorative treatment here rather than solely a functional surface treatment (cf. Rice 1987:138), though a roughened and brushed pot would have been easier to pick up and carry than would an unroughened or smoothed vessel. Smoothing creates "a finer and more regular surface...[and] has a matte rather than a lustrous finish" (Rice 1987:138). Burnishing, on the other hand, creates an irregular lustrous finish marked by parallel facets left by the burnishing tool (perhaps a pebble or bone). A polished surface treatment is marked by a uniform and highly lustrous surface finish, done when the vessel is dry, but without "the pronounced parallel facets produced by burnishing leather-hard clay" (Rice 1987:138). The application of a hematite-rich clay slip (Ferring and Perttula 1987), either red or black after firing, is another form of surface treatment noted in this assemblage. The clay slip is more frequently applied on the vessel exterior than on the interior surface, and then was either burnished or polished after it was leather-hard or dry. In several other instances, the hematite-rich clay was applied as a pigment to engraved designs on bottles and carinated bowls; no white kaolin-rich pigments were noted in the sherd assemblage from the Nawi haia ina site, however.

Decorative techniques present in the Nawi haia ina site ceramic sherd assemblage include engraving, incising, punctating, brushing, lip notching, and appliqueing, and on certain vessels, combinations of decorative techniques (i.e., brushed-incised, incised-punctated, or brushed-punctated, etc.) created the decorative elements and motifs. Engraving was done with a sharp tool when the vessel was either leatherhard, or after it was fired, while the other decorative techniques were executed with tools (incising, lip notching, and punctation with wood or bone sticks or dowels), by adding strips of clay to the wet body (applique), using frayed sticks or grass stems (brushing) across the body surface, or fingernails and cut pieces of cane (certain forms of punctations), when the vessel was wet or still plastic.

The sherds from the Nawi haia ina site are readily separated into utility wares or fine wares, following the distinctions discussed by Schambach and Miller (1984) at the Cedar Grove site (3LA97) in the Great Bend area in southwestern Arkansas. These distinctions include apparent differences in temper, surface treatment, vessel forms, and decorative methods. Utility wares generally are jars and simple bowls used for the cooking and storage of foods, have a coarse temper, and lack burnishing, polishing, or slipping on interior and exterior vessel sherd surfaces. Such vessel sherds are decorated with brushing, incising, punctations, and appliqued elements, either by themselves or in combination with one or more of these decorative methods (see Rogers and Perttula 2004; Schambach and Miller 1984; Suhm and Jelks 1962). Fine wares, on the other hand, at the Nawi haia ina site consist principally of engraved, engravedslipped, engraved-pigment, and slipped vessel sherds from carinated bowls, some simple bowls, and bottles. The fine ware vessels and vessel sherds more frequently are smoothed, burnished, and/or polished on the exterior vessel surface, and as will be discussed in more detail below, the fine ware vessels from the Nawi haia ina site were made, fired, and used in different ways than were the utility ware vessels. 


\section{The Ceramic Assemblage}

The ancestral Caddo ceramic assemblage from the Nawi haia ina site includes 2550 vessel sherds (25.7 percent of which have decorations), and several long-stemmed Red River pipe bowl and stem sherds. About 87 percent of the ceramic sherds are from the midden deposits and features in the trench unit excavations, with the remainder from surface collections in the midden and burial areas $(n=232)$, from shovel testing $(n=61)$ in the same areas, and miscellaneous backhoe contexts $(n=34)$ in the vicinity of the Caddo burials.

By level in the midden area excavations, the highest numbers of sherds are from $10-30 \mathrm{~cm}$ bs $(n=1253$ or 59 percent), followed by $30-40 \mathrm{~cm}$ bs $(n=384$ or 18.3 percent) and $0-10 \mathrm{~cm}$ bs $(n=335$ or 15.9 percent). Less than 7 percent of the sherds are from depths below $40 \mathrm{~cm}$ bs. In weighing a sample of 20 percent of the midden sherds (for use in estimating the accumulation rate of utility and fine ware sherds as a proxy for occupation duration), the mean weight of a sherd is $5.65 \mathrm{~g}$. The deposits between $20-50 \mathrm{~cm}$ have significantly larger and heavier sherds than the overall mean weight, ranging between 5.79-7.78 $\mathrm{g}$ per sherd. On average, the largest sherds are from $30-40 \mathrm{~cm}$ bs, and the smallest sherds ( $3.83 \mathrm{~g}$ per sherd) are from $50-60 \mathrm{~cm}$ bs.

In the analysis that follows, the discussion of the Nawi haia ina ceramics is based on the detailed analysis of the 651 decorated sherds and a sample of 568 plain sherds, including 92 plain rims, in the collection. The sample of the plain rim, body, and base sherds is more than reasonable-since it is from a single archaeological component - to accurately characterize the temper, paste, vessel wall thickness, firing conditions, surface treatment, etc. in this class of sherds, keeping in mind that similar information has also been obtained from all the decorated sherds.

There is considerable similarity in sherd decorations, temper, paste, and firing conditions between the different levels in the midden, and from general surface contexts. Within that component, there may be archaeological evidence of at least two or three separate occupational episodes, as demonstrated by the calibrated radiocarbon dates from midden deposits As such, the discussion of sherd attributes and variables focuses on characterizing the ceramic assemblage as a whole for this apparent Middle Caddo period component - and by utility ware and fine ware groups - rather than by the different intra-site proveniences.

\section{Decorated Sherds}

There are 651 decorated sherds in the Nawi haia ina site ceramic assemblage (Table 2), including 107 rim sherds and 544 body sherds. The fine ware sherds $(n=146)$ from the site comprise approximately 22.4 percent of the vessel sherds in the collection; the utility ware sherds represent the remaining 77.6 percent of the decorated sherd assemblage. If we compare the proportions of utility ware to fine ware sherds simply employing the percentage of rim sherds - probably a better measure of the frequency of different vessel forms at the site -29 percent of the rim sherds are from engraved fine wares, and 71 percent of the rims are from utility ware vessels. The utility ware sherds clearly dominate the vessel ceramics from the site, particularly those from incised-punctated, incised, and tool punctated vessels. There are several rarely found but apparently diagnostic Middle Caddo kinds of decorated sherds at Nawi haia ina, namely lip notched sherds and rim sherds with clay tabs; these represent six different vessels. At the nearby Oak Hill Village site (41RK214), there were four different vessels represented by lip notched and rim tab sherds (see Rogers and Perttula 2004:Table 58). 
Table 2. Summary of decorated sherds from the Nawi haia ina site.

\begin{tabular}{|c|c|c|c|}
\hline Decorative Method & Rim Sherd & Body Sherd & $\mathrm{N}$ \\
\hline \multicolumn{4}{|l|}{ Utility Wares } \\
\hline Incised-punctated & 12 & 92 & 104 \\
\hline Incised & 31 & 136 & 167 \\
\hline Incised-appliqued & - & 1 & 1 \\
\hline Tool punctated & 19 & 85 & 104 \\
\hline Fingernail punctated & - & 49 & 49 \\
\hline Fingernail-tool punctated & - & 1 & 1 \\
\hline Cane punctated & 6 & 30 & 36 \\
\hline Cane punctated-tool punctated & - & 1 & 1 \\
\hline Large circular punctated & 1 & 3 & 4 \\
\hline Brushed & 1 & 17 & 18 \\
\hline Brushed-punctated & 1 & 11 & 12 \\
\hline Brushed-incised & - & 1 & 1 \\
\hline Brushed-punctated-incised & - & 1 & 1 \\
\hline Brushed-appliqued & - & 1 & 1 \\
\hline Lip notched & 3 & - & 3 \\
\hline Lip notched-punctated & 2 & - & 2 \\
\hline \multicolumn{4}{|l|}{ Fine Wares } \\
\hline Engraved, bowl sherds & 29 & 76 & 105 \\
\hline \multicolumn{4}{|l|}{ Engraved, bowl sherds with } \\
\hline Red pigment & 1 & 3 & 4 \\
\hline Engraved, bottle sherds & - & 27 & 27 \\
\hline \multicolumn{4}{|l|}{ Engraved, bottle sherds with } \\
\hline Red pigment & - & 7 & 7 \\
\hline Red-slipped & - & 2 & 2 \\
\hline Rim tab & 1 & - & 1 \\
\hline Totals & 107 & 544 & 651 \\
\hline
\end{tabular}

The plain/decorated sherd ratio (P/DR) at the site is a relatively low 2.92. Other Middle Caddo sites in the region (but in the Sabine River basin) have P/DR values that range from 1.30-2.65 (Perttula, ed., 2002:368), including 1.32-1.63 at the Oak Hill Village (ca. A.D. 1150-1400, see Rogers and Perttula 2004), 1.56 at 41RK243 (ca. A.D. 1250-1450, see Perttula 2001), and 1.91 at the Tom Moore site (41PN149, ca. A.D. 1300-1400, see Haskins and Walters 2001). Although these sites are contemporary with the Nawi haia ina site, they tend to have greater proportions of decorated utility wares (particularly brushed pottery), which results by comparison in lowered P/DR values.

\section{Utility Wares}

As I discussed above, the utility ware sherds from the Nawi haia ina site are primarily from incised, incised-punctated, and tool punctated vessels, most likely cooking jars and jars used for the storage of food stuffs. These three classes of decorated sherds comprise 82 percent of the utility ware rims and 73 percent of the utility ware decorated body sherds (see Table 2). Here, I discuss the principal decorative elements and motifs that are recognizable in the ceramic assemblage. 


\section{Incised-punctated sherds}

The incised-punctated sherds from the Nawi haia ina site include 12 rims and 92 body sherds. The punctated elements in most cases are tool punctations, with a number of cane punctated elements, and only a very few $(n=2)$ incised and fingernail punctated decorations; fingernail punctated elements seem to be almost exclusively confined to the bodies of utility ware vessels.

Among the rim sherds, there is a wide variety of incised-punctated decorative elements. The largest rim has opposed sets of diagonal incised lines between triangular zones filled with linear tool punctations (Figure 6). There is another rim that has a single set of diagonal incised lines adjacent to a tool punctated-filled triangular zone.

Several other rims $(n=3)$ have at least one or two horizontal incised lines, with one row of tool or cane punctations either below the lip (see Figure 9d below) or below the first horizontal incised line. Another has a zone of tool punctations - in three rows - below the lip but above a single horizontal incised line. Related to these is a peaked rim vessel (Figure 7a) with two sets of slanting incised lines, with a group of small tool punctations below the rim peak and between the two incised lines. Suhm and Jelks (1962:Plate 16a) illustrate a Crockett Curvilinear Incised peaked vessel

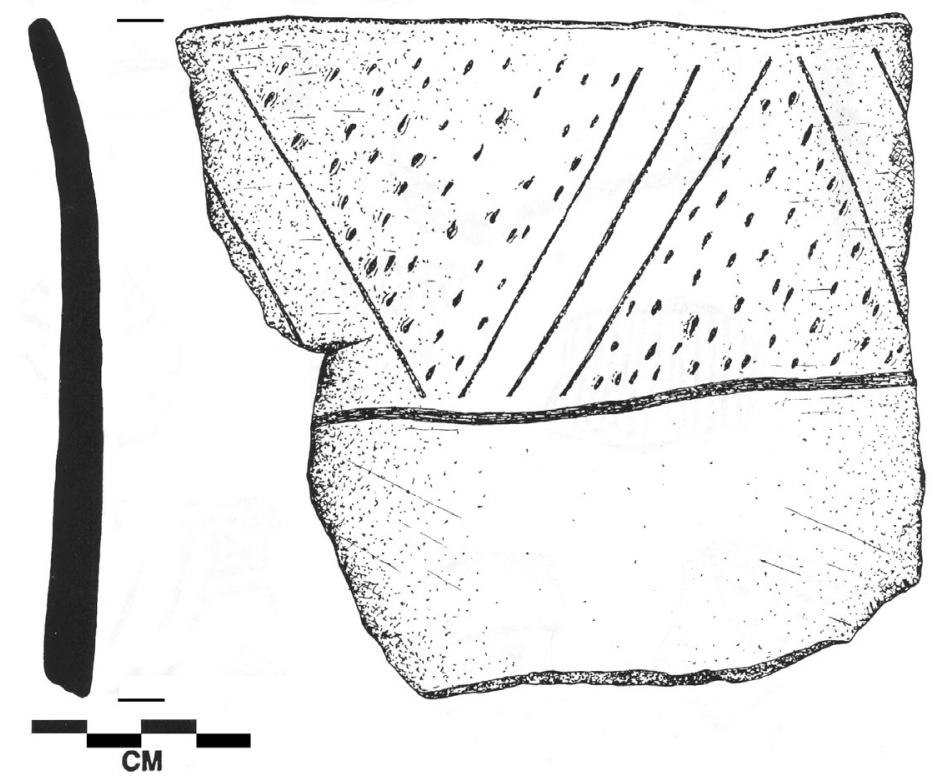

Figure 6. Incised-punctated rim sherd, Unit $23,20-30 \mathrm{~cm}$ bs, at the Nawi haia ina site.

of similar shape and decoration, but without the small group of tool punctations below the rim peak, and the Nawi haia ina site vessel is otherwise undecorated on the rim below the two horizontal incised lines. Another peaked rim vessel (Figure 8a-b) had at least four diagonal rows of tool punctations above a single horizontal incised line at the rim-body juncture.

Three other rim sherds have either diagonal or vertical incised lines that divided the rim into rectangular panels filled with tool punctations. The remaining incised-punctated rim sherds have curvilinear incised lines along the rim, creating oval to semi-circular zones filled with tool punctations (see Figure 7b).

Among the incised-punctated body sherds, most have linear or rectilinear incised zones filled with tool punctations $(n=39)$ (see Figure $7 \mathrm{j})$, followed by triangular-incised tool punctated-filled zones $(n=13)$ (see Figure $7 \mathrm{~g}$, i) and linear/rectilinear incised zones filled with cane punctations $(\mathrm{n}=8)$. Circular incised zones are filled with cane $(n=6$, see Figure $7 e-f)$ and tool punctations $(n=5)$.

On sherds where at least some portion of a recognizable decorative element could be defined, 68 percent of the incised-tool punctated sherds have linear to rectilinear incised zones filled with tool punctations. Another 23 percent have triangular incised zones filled with punctations (see Figure $7 \mathrm{~g}$ ), and only 9 percent have circular or semi-circular incised zones filled with tool punctations. One of the latter (see Figure 7h) has punctations within a set of three semi-circular incised lines, but the punctations spilled out across the lower part of the semi-circle and were further defined by a set of three straight lines opposed to the set of semi-circular incised lines. On 33 body sherds, the orientation of the incised zone could not be determined, and these had between 1-5 rows of tool punctations alongside one side of a straight incised line. 

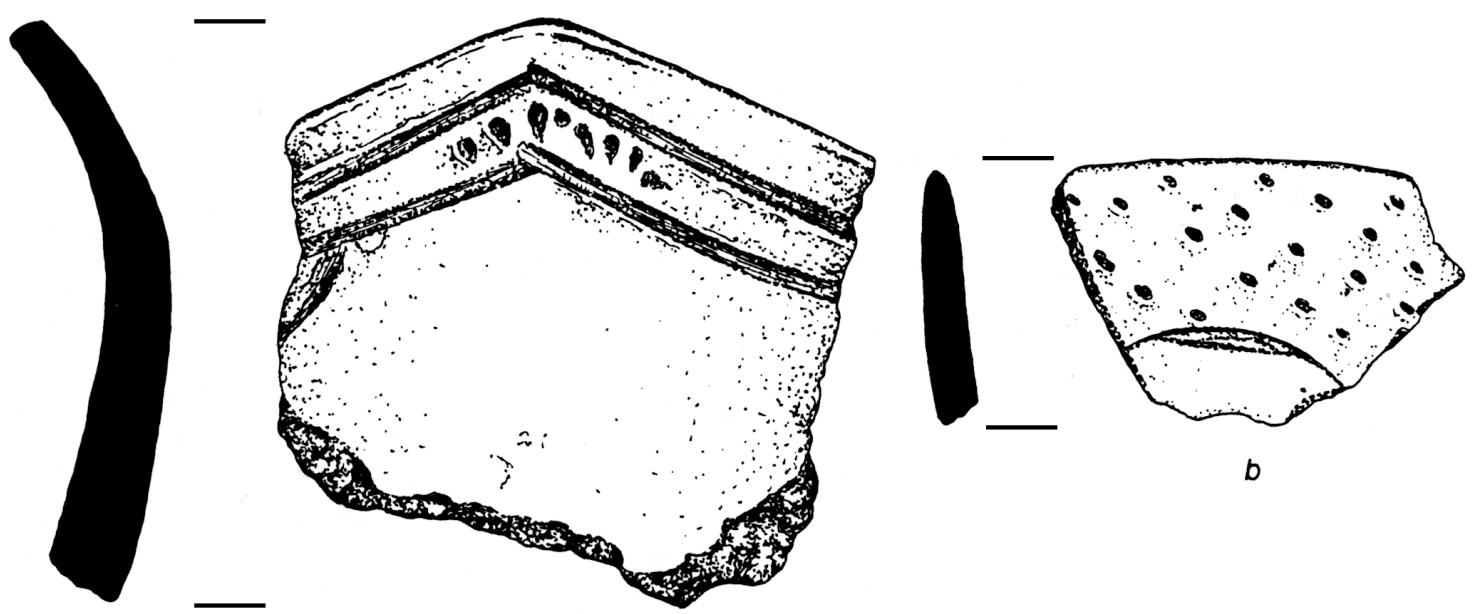

a
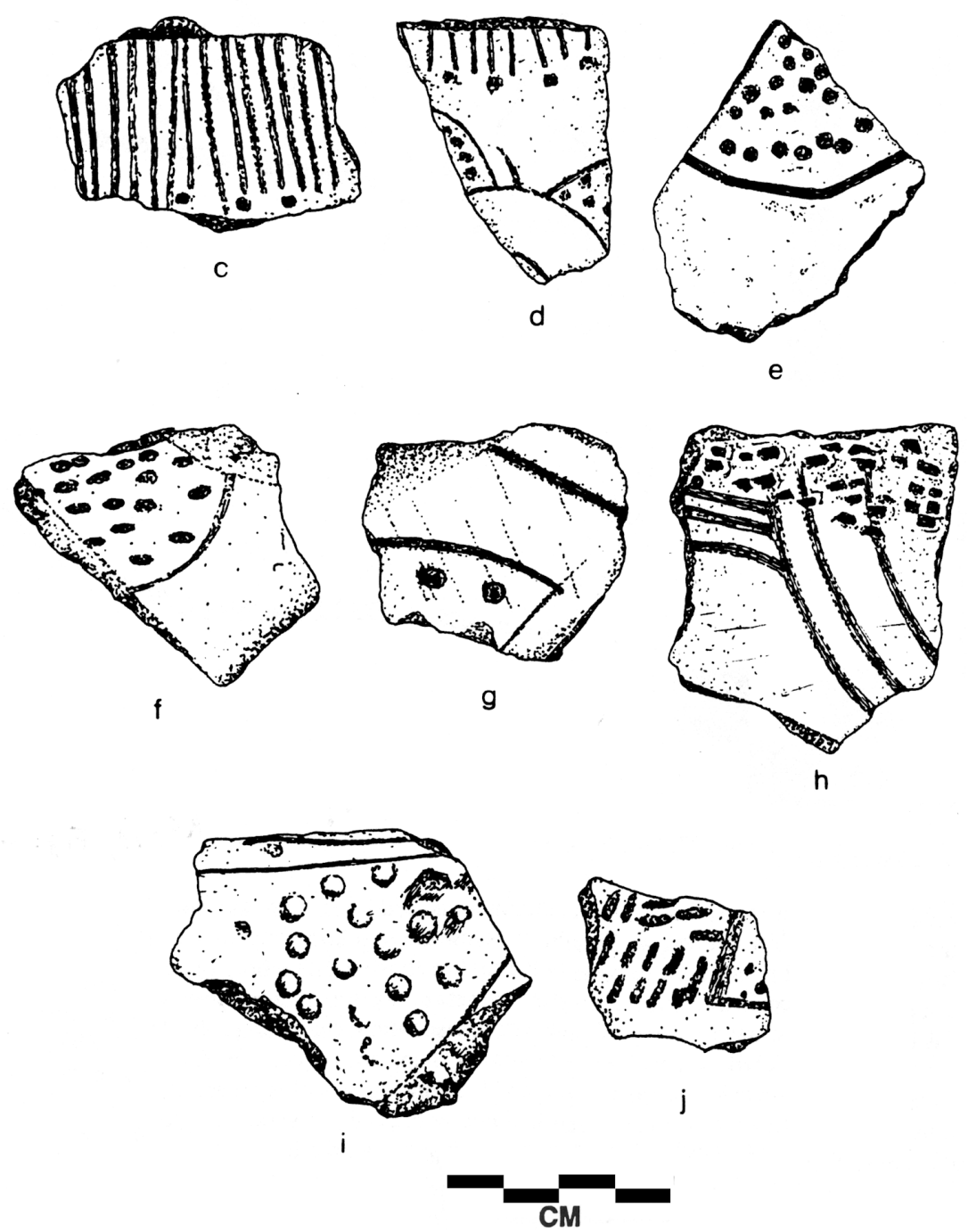

Figure 7. Incised-punctated rim and body sherds from the Nawi haia ina site. Provenience: a, Unit 30, 0-10 cm; b, Feature 2; c, Unit 30, 10-20 cm; d, Unit 30, 20-30 cm; e, general surface; f, Unit 31, 30-40 cm; g, Unit 15, 10-20 cm; h, Unit 29, 30-40 cm; i, Unit 29, 0-10 cm; j, Feature 2 extension, 20-30 cm. 

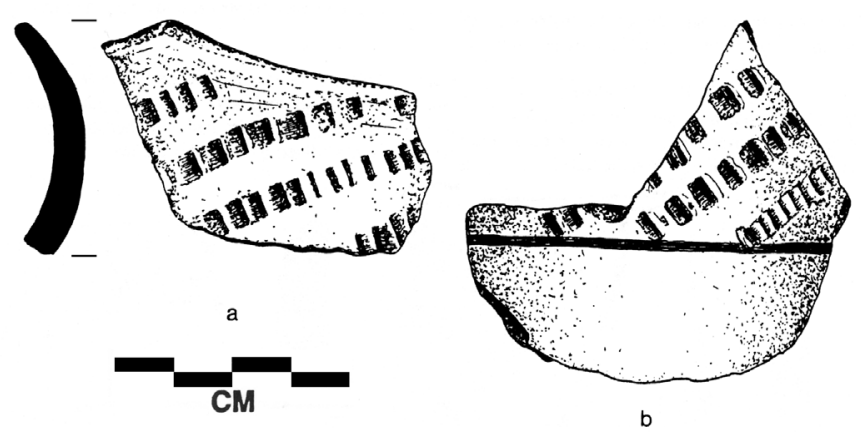

Figure 8. Distinctive punctated and incised-punctated sherds from the same vessel at the Nawi haia ina site: a, Unit 20, 10$20 \mathrm{~cm}$; b, Unit 19, 20-30 cm bs.

The cane punctated-incised body sherds have both linear/rectilinear $(n=8)$, triangular $(n=4)$, and circular-filled zones $(n=6)$, with the latter proportionally most prevalent at the Nawi haia ina site. Four of the most distinctive cane punctated-incised sherds have sets of curvilinear incised lines with small semi-circles pendant from the outermost incised line. These small semi-circles are filled with tiny cane punctations (see Figure 7d). A larger sherd with the same decorative element also has a line of cane punctations above the small semi-circles, and this cane punctated row is at the bottom of a series of closely-spaced and vertically incised lines (see Figure 7c).

The two incised and fingernail punctated body sherds include one with a single straight incised line bisected by a row of fingernail punctations, and with at least another row of punctations above the incised line. The other has a vertical incised panel, with the rectilinear panel filled with rows of fingernail punctations.

\section{Incised}

There are 31 incised rim sherds and 136 body sherds in the Nawi haia ina ceramic collection (see Table 2). More than 33 percent of the utility ware sherds from the site have incised decorations, and the incised sherds are the most common decorated utility ware.

Among the rims, the most frequent decorative element are sets of equally-spaced diagonal lines $(n=15)$, all pitched in one direction. Cross-hatched incised rims were also popular (Figure 9c), as there are seven in the collection. In the case of six of the rims, the cross-hatching begins immediately below the lip, while on a seventh, the cross-hatched incising begins below an undecorated panel under the lip.

Four other incised rims have a single horizontal line below the lip, and a fifth has a single horizontal line with diagonal lines extending down the rim from that line; this particular decorative element resembles certain Dunkin Incised specimens (see Suhm and Jelks 1962:Plate 19h). Other rims have opposed diagonal lines $(n=1)$, sets of vertical incised lines $(n=1)$, and opposed incised zones (see Figure $9 b$ ). The most distinctive incised rim has a set of curvilinear to semi-circular incised lines around a semicircular zone filled with cross-hatched incised lines (see Figure 9a).

In the body sherds, one of the more recognizable incised elements is cross-hatched lines $(n=15)$, followed by sherds with multiple and parallel sets of incised lines $(n=29)$; the orientation of the incised lines cannot be determined. Several $(n=10)$ also have 1-3 curvilinear lines - orientation unknownincluding one body sherd with opposed sets of broad curvilinear incised lines (see Figure 9e) and another with opposed sets of straight lines. One body sherd has obvious horizontal lines on it, and another has a set of diagonal incised lines. 

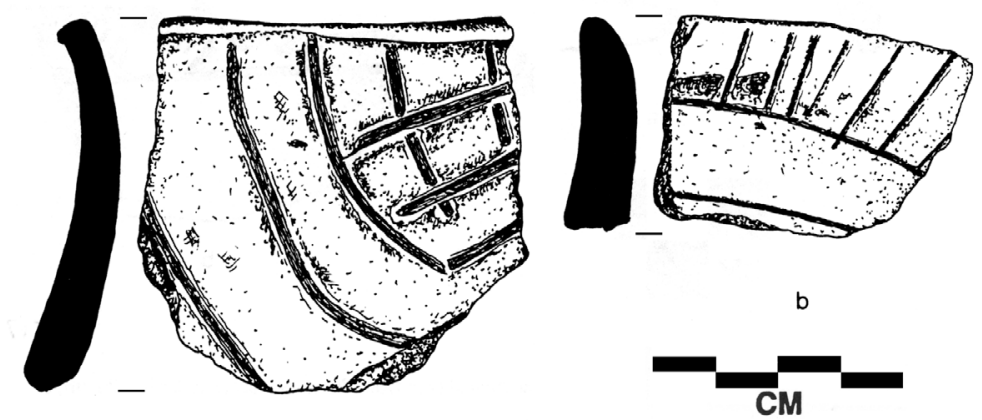

a

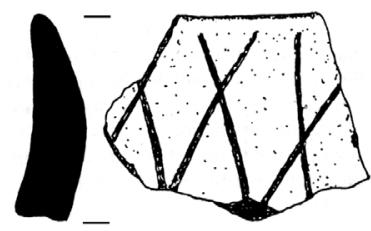

c

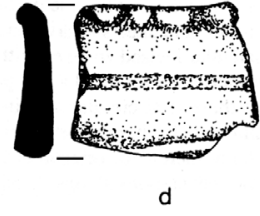

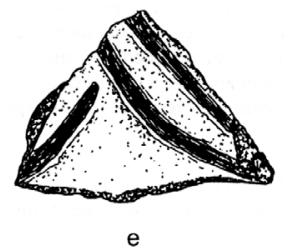

Figure 9. Incised rim and body sherds from the Nawi haia ina site. Provenience: a, Unit 22, 30-40 cm; b, Unit 22, 30-40 cm; c, general surface; d, Unit 15, 0-10 cm; e, ST 7, 0-20 cm.

More distinctive incised sherds have rectilinear elements, with sets of lines opposing each other, and sometimes forming small incised-filled triangles or nested sets of triangles $(n=4)$. Others simply have opposed sets of lines, either pitched in opposite diagonal directions $(n=18)$, or pitched perpendicular to each other $(n=9)$. Two other body sherds have sets of straight lines that parallel somewhat randomlyplaced cross-hatched incised elements.

\section{Incised-appliqued}

The one incised-appliqued body sherd is from Feature 4 in the trench unit midden (see Figure 11d). The body sherd has diagonal opposed appliqued ridges parallel to sets of diagonal incised lines

\section{Tool punctated}

The tool punctated sherds are the most common of the various punctated rim and body sherds in the Nawi haia ina site collection. They account for almost 21 percent of all the decorated utility wares from the site, and outnumber the fingernail and cane punctated sherds by ratios of 2.1:1 and 2.9:1, respectively (see Table 2). Previous ceramic analyses of Middle Caddo sites in the region suggest that through time in the Middle Caddo period, tool punctated vessel sherds become more and more common relative to the frequency of fingernail punctated sherds (see Perttula 2001).

Most of the tool punctated rim sherds $(n=15)$ have between 2-7 horizontal rows of punctations beginning below the lip of particular vessels (Figure 10a, d). Three rims, however, have diagonal rows of tool punctations (Figure 10b). One distinctive peaked rim vessel from Unit $20(10-20 \mathrm{~cm})$ had at least four diagonal rows of rectangular tool punctations (see Figure 8a) on the rim, but this rim was conjoined with another sherd from Unit $19(20-30 \mathrm{~cm})$ that indicates the diagonal rows terminate at a broad horizontal incised line at the rim-body juncture. None of the other tool punctated rims, however provide any hint that they are decorative elements in a larger or more complicated incised-punctated motif. 

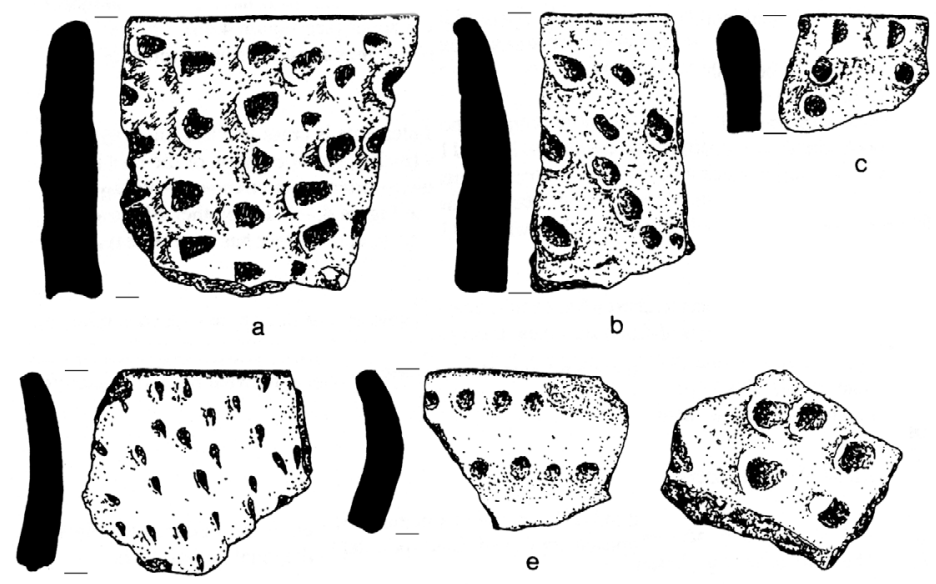

d
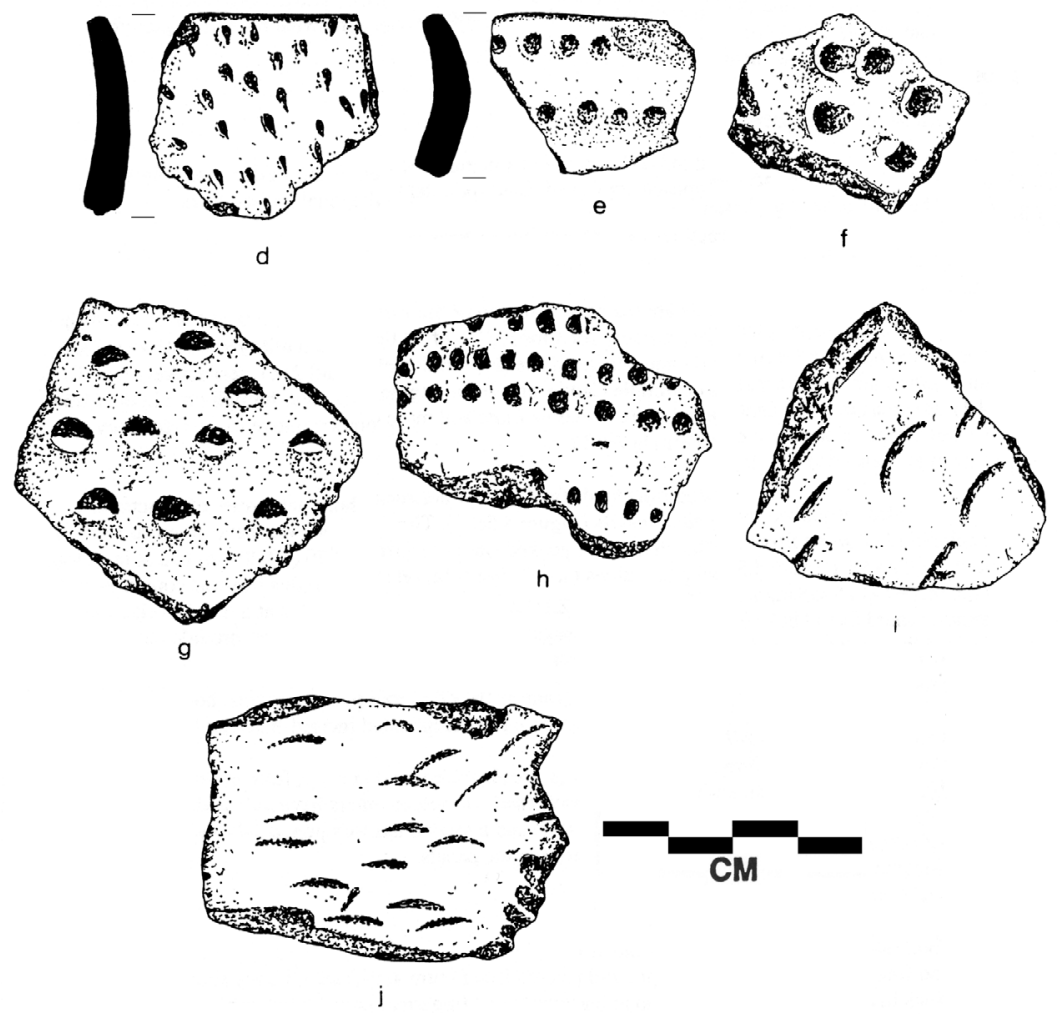

Figure 10. Tool and fingernail punctated rim and body sherds from the Nawi haia ina site. Provenience: a, Unit 12, 10-20 cm; b, Unit 30, 40-50 cm; c, Unit 20, 10-20 cm; d, Unit 14, 40-50 cm; e, surface; f, Unit 29, 40-50 cm; g, Unit 13, 10-20 cm; h, Unit 32, 30-40 $\mathrm{cm}$; i, Unit 12, 0-10 cm; j, Unit 20, 0-10 cm.

The tool punctated body sherds are also decorated in rows, from at least one row $(n=28)$, two rows $(n=28)$, three rows $(n=12)$, and four rows $(n=1)$. Fourteen others have only a single tool punctation. One body sherd has linear tool punctations in a row, and a second has tool punctated rows in at least two panels separated by an undecorated space between the panels.

\section{Fingernail punctated}

The 49 fingernail punctated sherds (see Figure 10i-j) are all body sherds from utility ware vessels. The absence of rim sherds strongly suggests that fingernail punctations were a decoration restricted to the body of vessels rather than the rim and body. The fingernail punctations were placed on the vessel body in roughly aligned rows (whether horizontally or vertically oriented cannot be determined), and as many as four rows of punctations have been identified on particular sherds. Most of these sherds, however, have at least one $(n=11)$, two $(n=13)$, or three $(n=10)$ rows of fingernail punctations. 


\section{Fingernail-tool punctated}

This is a body sherd from the surface collection that has both fingernail punctations and tool punctations. The fingernail punctations occur in a single row, with parallel rows of tool punctations above it.

\section{Cane punctated}

The cane punctated rim and body sherds are from utility ware vessels that appear to have been solely decorated with cane punctations of different sizes (see Figure 10f-h). The six rim sherds all have between 1-4 rows of small cane punctations, as do 23 body sherds. Two body sherds have 1-4 rows of large cane punctations. Five small sherds have only a single small cane punctation.

\section{Cane punctated-tool punctated}

One body sherd from Unit $24(20-30 \mathrm{~cm})$ has sets of diagonally-oriented punctations. One set was made with a circular-shaped cane and the other was made with a small rectangular tool or dowel. It is unusual to have vessels decorated with two different kinds of punctations, although there is also a fingernail-tool punctated sherd in the surface collection from the Nawi haia ina site (see above).

\section{Large circular punctated}

The four large circular punctated sherds include a rim (see Figure 10e) and three body sherds. The distinctive character of these sherds is the larger than usual rows of circular punctations on the rim and/or body of utility ware vessels.

\section{Brushed}

Brushed sherds at the Nawi haia ina site include one rim (Unit 22, 20-30 cm) and 17 body sherds (see Table 2); they amount to 3.6 percent of the utility wares. Including all sherds with some brushing (often with other decorative elements, such as punctations or incised lines), the brushed sherds comprise 6.5 percent of the utility wares. This is a relatively low frequency of brushing in a Middle Caddo site (e.g., Rogers and Perttula 2004; Perttula 2001, 2013; Haskins and Walters 2001), where brushed sherds may represent $25-40$ percent of all the decorated sherds from particular sites, but may be consistent with much of the ceramic assemblage dating between ca. A.D. 1185-1270.

The one rim has horizontal brushing across it, from just below the lip to the rim-body juncture. Most of the body sherds $(n=14)$ have parallel brushing marks (Figure 11a), where the orientation of the brushing cannot be determined. Two others have overlapping brushing marks, and a third (Unit 34, 20-30 $\mathrm{cm}$ ) has been vertically brushed on the vessel body of a cooking jar.

\section{Brushed-punctated}

Brushed-punctated sherds comprise 2.4 percent of the decorated utility ware at the site, and include one rim (Unit 35, 0-10 cm) and 11 body sherds (see Table 2). The rim has horizontal brushing on it, with a row of tool punctations along the rim-body juncture, but not pushed through the brushing. 


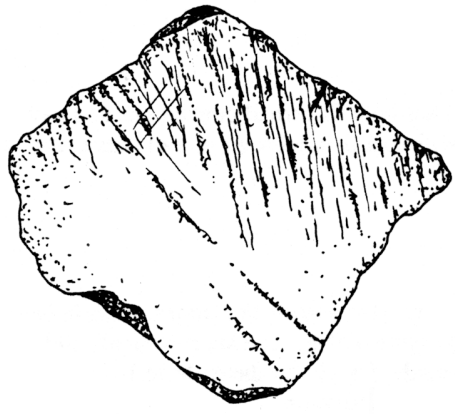

a

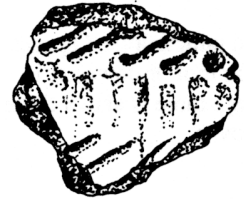

C

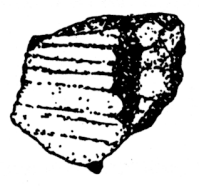

b
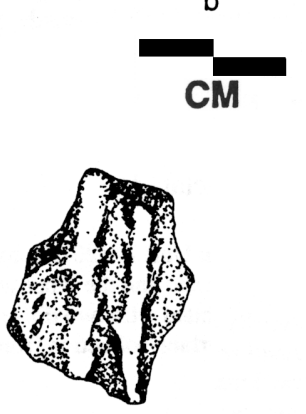

Figure 11. Brushed, brushed-appliqued, brushedpunctated, and appliqued-incised body sherds from the Nawi haia ina site: Provenience: a, Unit 25, 0-10 cm; b, Unit 22, 20-30 cm; c, general surface; d, Feature 4.

Most of the body sherds, however, have brushing marks (either parallel [n=9], overlapping [ $n=1]$, or diagonal $[n=1]$ ) with rows of either tool or fingernail punctations pushed through the brushing (see Figure 11c). Only the one brushed-fingernail punctated body sherd and the diagonal brushed-linear punctated body sherd do not have punctations that have been pushed through the brushing; in these rare cases, the punctations are in a row below the brushing, probably marking a rim-body juncture, or a vertical panel on the body. In the others, the punctations occur in rows within the brushing.

\section{Brushed-incised}

There is only a single brushed-incised body sherd (Unit 22, 20-30 cm) in the Nawi haia ina ceramic assemblage (see Table 2). It has parallel brushing marks amidst a broader spacing of parallel incised lines.

\section{Brushed-punctated-incised}

This sherd, found on the surface, has a set of diagonal incised lines on the lower part of the rim, with a horizontal row of tool punctations at the rim-body juncture. The body has vertical brushed lines with diagonal rows of punctations pushed through the brushing. The decorative element is obviously related to the Pease Brushed-Incised and Reavely Brushed-Incised types (see Suhm and Jelks 1962; Hart 1982, 2014).

\section{Brushed-appliqued}

The one brushed-appliqued body sherd (Unit 22, 20-30 cm) has a narrow appliqued fillet that runs perpendicular to areas covered with brushing marks (see Figure 11b). The appliqued fillet probably is vertically-oriented on the vessel body of a jar, the fillet dividing the body into sets of panels filled with horizontal brushing. 


\section{Lip notched}

The three lip notched rims were found in the trench unit midden (Unit 31, 20-30 cm and Unit 32, $40-50 \mathrm{~cm})$ and in excavations around Feature $1(25-35 \mathrm{~cm})$. All three have equally spaced $(3.5 \mathrm{~mm}$ apart $)$ and short perpendicular notches on the lip, and the rim itself appears to be undecorated.

\section{Lip notched-punctated}

Two other lip-notched rim sherds (Unit 17 and Unit 20,10-20 cm bs) are on vessels that are also decorated with rows of either tool or cane punctations on the rim itself (see Figure 10c).

\section{Fine wares}

The 146 fine ware sherds include 31 rims and 115 body sherds (see Table 2). These include engraved and slipped bottle sherds, and one rim tab from a bowl.

\section{Engraved, bowl sherds}

There are 109 engraved bowl sherds, including four with a red pigment smeared on them (see Table 2). These sherds account for 75 percent of the fine wares at the Nawi haia ina site, and almost 17 percent of all the decorated sherds in the assemblage.

Among the rim sherds, the most common decorative elements (or partial elements) are a single or multiple horizontal engraved lines $(n=8)$ or diagonal engraved lines $(n=3)$. The other decorative elements are represented by only one or two separate rim sherds. Immediately recognizable is a Holly Fine Engraved rim (Figure 12e) with horizontal and diagonal lines between excised triangles. Three other rims have small triangular engraved elements (Figure 12d) pendant from the rim or a horizontal engraved line below the lip. An opposed diagonal engraved rim (Figure 12g) basically depicts a series of large triangles pendant from the rim. A more crudely-executed rim has a diagonally engraved triangular element pendant from the rim, and resting above a series of closely-spaced horizontal engraved lines (Figure 12c).

Another rim has both vertical and diagonal lines, with the vertical lines creating panels filled with diagonal lines pitched in opposite directions from panel to panel. A second vertically engraved rim has a panel filled with a series of five horizontal lines.

One carinated bowl has a broad diagonal engraved zone filled with cross-hatching, while a second rim has a single horizontal engraved line midway down the rim and with a series of closely-spaced diagonal lines pendant from it. A third small rim has two horizontal lines connected with at least one vertical engraved line. Finally, another rim with vertical engraved lines has a curvilinear hatched zone adjacent to it, probably filling a series of panels repeated around the vessel rim.

The remainder of the engraved carinated bowl and bowl rim sherds have curvilinear and semicircular decorative elements. One has a series of widely-spaced curvilinear lines that slant across the rim (see Figure 12f), while two others have only a single curvilinear engraved line. Another rim-resembling Poyner Engraved (cf. Suhm and Jelks 1962:Plate 62I) and dating earlier than ceramic assemblages in the Neches-Angelina river basins with Poynor Engraved, but probably stylistically related - has at least two sets of three closely-spaced curvilinear engraved lines (see Figure 12b). A carinated bowl rim from Unit 23 has both curvilinear and circular decorative elements, in this case a curvilinear engraved line delineating an area filled with a cross-hatched circular to oval-shaped zone (see Figure 12a).

The last engraved rim is from a compound bowl (see Figure 12h). The upper part of the rim has a single horizontal engraved line with short vertical lines extending upwards towards the lip. The lower panel has a semi-circular and rectilinear motif. 


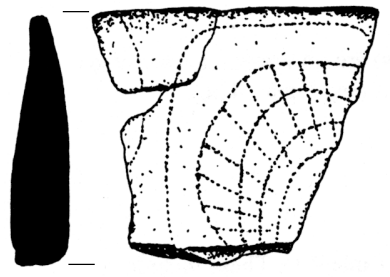

a
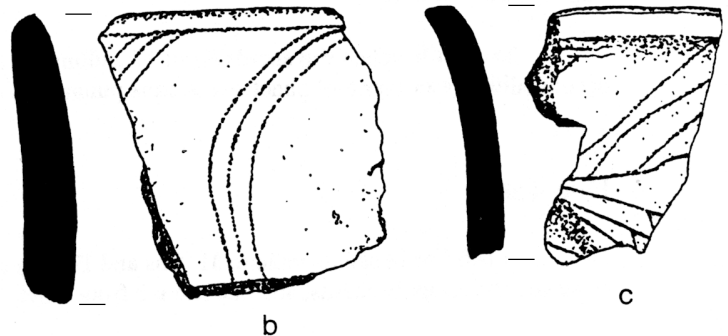

C

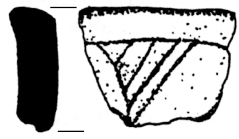

d

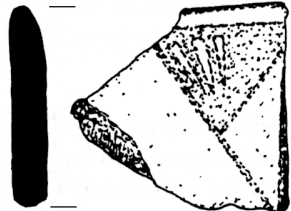

e
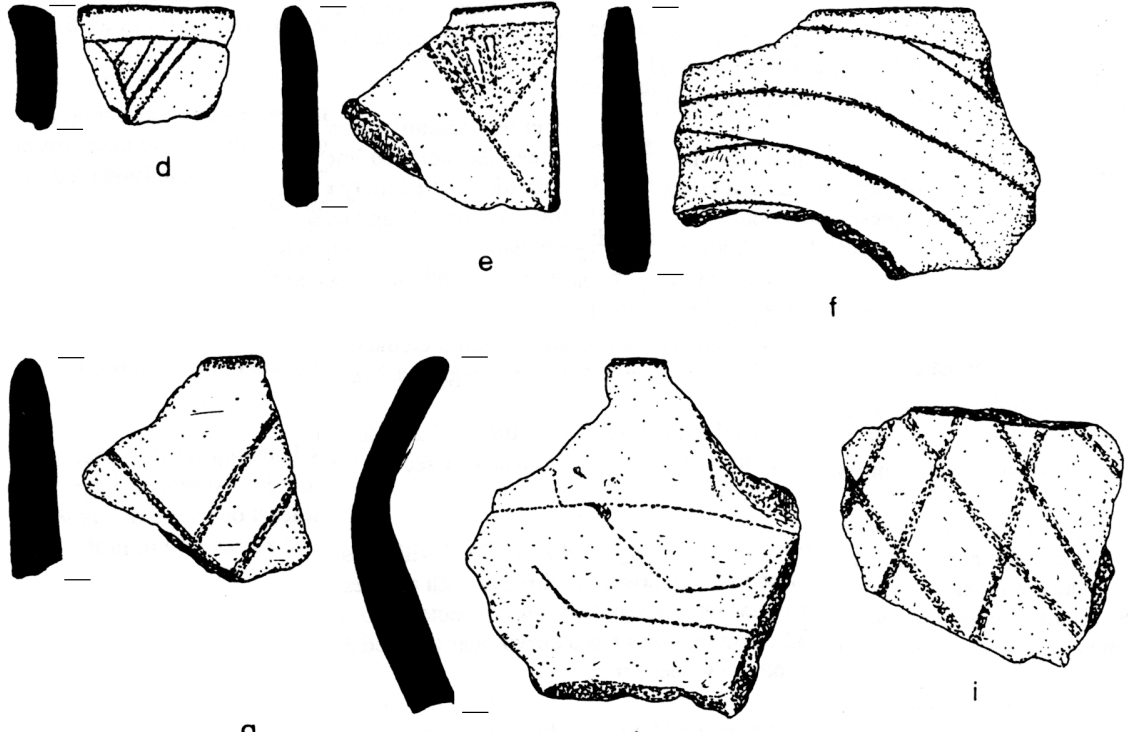

g

h
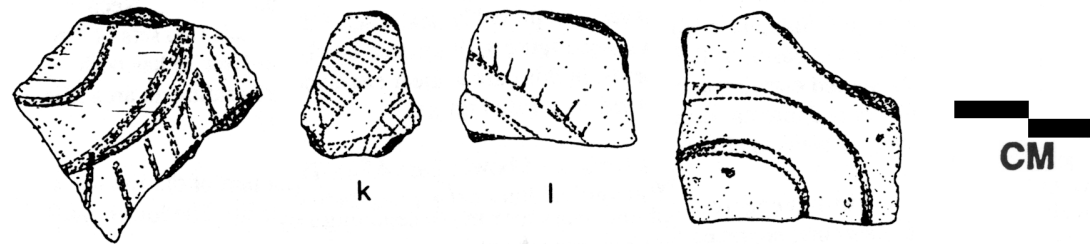

Figure 12. Engraved rim and body sherds from the Nawi haia ina site.

Provenience: a, Unit 23, 30-40 cm; b, Unit 17, 10-20 cm; c, Unit 12, 10 $20 \mathrm{~cm}$; d, Unit 32, 20-30 cm; e, Unit 24, 0-10 cm; f, Unit 22, 40-50 cm; g, Unit 14, 40-50 cm; h, Unit 25, 20-30 cm; i, found associated with Feature 1, Vessel 1; j, Unit 30, 10-20 cm; k, Unit 29, 40-50 cm; 1, Unit 23, 0-10 cm; m, Unit $18,10-20 \mathrm{~cm}$.

The 76 body sherds from engraved carinated bowls and simple bowls are dominated by sherds of indeterminate style with multiple parallel engraved lines $(n=16)$ and those with a single straight engraved line $(n=12)$. Other common engraved decorative elements in the Nawi haia ina site ceramics include diagonal lines $(n=2)$, cross-hatched lines $(n=3$, see Figure $12 i)$, and sets of curvilinear engraved lines (see Figure 12m).

Several body sherds $(n=10)$ have engraved filler zones from scrolls, ladders, and panel dividers (see Figure 12k), and these zones are either filled with hatched or cross-hatched lines. This decorative element is perhaps the most common engraved design recognized in the Oak Hill Village fine wares (Rogers and Perttula 2004:219, 221 and Figure 91c-f). 
Other engraved body sherds represented by more than one sherd include three with small pendant triangles and nine with multiple opposed lines, with the engraved lines pitched in opposite directions; an additional sherd has a small engraved triangle attached to a cross-hatched line. Four body sherds have horizontal and curvilinear elements, with one to multiple curvilinear lines radiating from the horizontal line, and a fifth engraved body sherd has opposed sets of curvilinear lines; the latter resembles the rim illustrated in Figure 12b, except the engraved lines on the body run in opposite directions from each other, while on the rim the set of curvilinear engraved lines repeat each other in the same direction around the rim.

Rectilinear elements on engraved body sherds include four relatively non-descript sherds. One has a branch-like design, with a central engraved line and at least seven lines radiating from it, and a second sherd has part of an engraved panel defined by two vertical lines, with the panel filled with a set of equally-spaced horizontal lines. A similar sherd has equally-spaced horizontal lines on both sides of the vertical engraved panel line. The last of these, from a carinated bowl, has a indeterminate portion of a horizontal and vertical engraved element.

There are a few body sherds with circular engraved elements. One of these has a portion of a large circle with several small engraved/excised triangles within it. Another has deeply engraved horizontal and curvilinear lines that surround a small engraved circle. The last one is an engraved circle filled with diagonal or hatched lines that radiate from the outermost part of the circle. This particular decorative element is virtually identical to three sherds with engraved element $25 \mathrm{c}$ at the Oak Hill Village site (Rogers and Perttula 2004:Figure 91n).

An unusual circular element on an additional sherd has two broad and curvilinear engraved lines with at least eight lines extending across the vessel body from the outermost curvilinear line (see Figure $12 \mathrm{j}$ ). Finally, one sherd has a portion of two curvilinear engraved lines, one of which joins with part of a triangular element.

\section{Engraved, bowl sherds with red pigment}

The one engraved rim with red pigment has a single horizontal engraved line below the lip, with at least two hatched pendant triangles; the pigment is smeared in both the pendant triangles and the horizontal engraved line. A similar design on another rim does not have pigment smeared in it.

Three body sherds have a red pigment. One has a cross-hatched element above a horizontal engraved line that must encircle the vessel rim. A second has a single curvilinear engraved line, and the third has opposed curvilinear lines.

\section{Engraved, bottle sherds}

There are 34 engraved bottle sherds in the ceramic assemblage, approximately 23 percent of the decorated fine wares (see Table 2). More than 20 percent of the bottle sherds have a red pigment smeared in the engraved lines, compared to only 3.7 percent of the engraved carinated bowl and bowl sherds. The bottle necks or rim sherds from the site are uniformly plain (see below), and the engraved decorations are restricted to the vessel body.

The most common decorative elements include sets of two or three curvilinear engraved lines $(\mathrm{n}=8$, including two with red pigment), and cross-hatched engraved zones $(\mathrm{n}=5)$. Another four bottle sherds have narrow hatched and/or hatched zones - this same decorative element is the most prevalent in the contemporaneous Oak Hill Village engraved bottle sherds (Rogers and Perttula 2004) - or cross-hatched triangular zones (Figure 13c). 

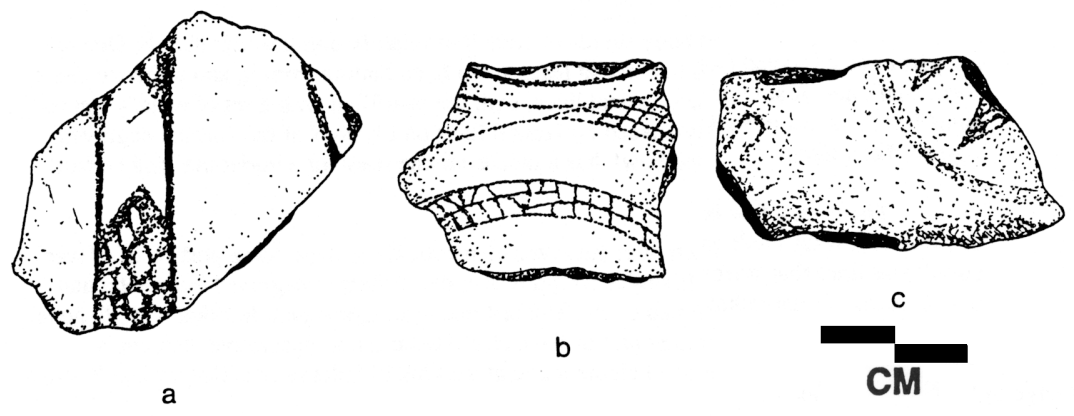

Figure 13. Engraved bottle sherds from the Nawi haia ina site. Provenience: a, Unit 29, 20-30 cm; b, surface; c, Feature 1, west extension.

Two other bottle sherds have diagonal opposed engraved lines on the vessel body, and another has horizontal and diagonal opposed lines. An unusual bottle sherd has an engraved ladder or branching lines, with a central line and eight engraved branching lines.

Probably the most unique of the engraved bottle sherds is one with a broad and parallel engraved zone filled with a triangular-shaped cross-hatched element (see Figure 13a). This distinctive fill element-ending in the triangular or pointed shape - is also seen on Middle Caddo bottles with engraved rattlesnake (canebrake rattler) motifs in the Big Cypress, Sabine, and Angelina river basins (Hart 1982, 2014; Corbin and Hart 1998:Figure 31; Perttula 2001:Figure 30i; Rogers and Perttula 2004:Figure 91p and Figure 92; Turner et al. 2003:Figure 12b, d-e; Walters 2006; Hart and Perttula 2010; Gadus 2013). Galan (1994) suggests that such engraved rattlesnakes may have symbolic associations with the Snake Woman of Caddo mythology (cf. Dorsey 1905), and may also have meaning in Caddo first corn rites.

\section{Engraved, bottle sherds with red pigment}

The bottle sherds with red pigment smeared in the engraved designs tend to have curvilinear engraved elements, either by themselves or in combination with hatched or cross-hatched filler zones (see Figure 13b), as do most of the bottle sherds from the Nawi haia ina site. One bottle sherd has only multiple parallel engraved lines, and a second has diagonal engraved lines with tick marks along one diagonal line (see Figure 121).

\section{Red-slipped}

The two red-slipped body sherds have a hematite-rich slip only on their exterior vessel surfaces, and are probably from bottles. The rarity of red-slipped sherds in the ceramic assemblage at Nawi haia ina is matched by the virtual absence (less than 1 percent) in other contemporaneous and nearby Middle Caddo sites (see Rogers and Perttula 2004; Perttula 2001; Haskins and Walters 2001).

\section{Rim tab}

The one rim tab sherd (Unit 30,10-20 cm bs) is from a grog-hematite-tempered vessel that was fired in a reducing environment. The tab is a piece of clay that has been joined onto the top of the vessel lip; rim tabs usually occur in sets or two or four along the vessel lip. It is $22.4 \mathrm{~mm}$ in width, and sticks up vertically $17.4 \mathrm{~mm}$ from the lip itself. 


\section{Rim Sherds}

There are 199 rim sherds in the detailed sherd analysis sample, 107 (54 percent) that are decorated and 92 are plain, including the rim tab. Most of the rim sherds are small in size, and only a few of them had sufficient curvature to provide information on the orifice diameters of the vessels they came from. Among the utility wares, 16 rim sherds had orifice diameters that ranged between 13-27 cm, indicating the use of small $(10-16 \mathrm{~cm})$, medium-sized $(18-20 \mathrm{~cm})$, and large $(25-27 \mathrm{~cm})$ vessels for cooking and some small-scale storage needs; much of the storage of plant foods and seeds was probably in aboveground granaries like those identified in the latest (ca. A.D. 1350+) village at the nearby Oak Hill Village site (Rogers and Perttula 2004). None of the utility wares even closely approached the "spectacularly large" size of vessels found on the floors of burned houses at the early $15^{\text {th }}$ century Tom Jones (3HE40) site in Hempstead County, Arkansas (Schambach 2002:7).

Two plain bottle necks had 3-4 $\mathrm{cm}$ orifice diameters, and several $(\mathrm{n}=11)$ small plain bowl rims were from vessels with 10-25 cm orifice diameters. The majority of the plain bowl rims are from small vessels (i.e., 10-17 cm) (Figure 14a-b). The six engraved rims with measurable orifice diameters ranged between $13-24 \mathrm{~cm}$ in size, again suggesting the use of primarily small and medium-sized vessels at the Nawi haia ina site for holding and serving foods, rather than the large serving vessels that may have been used in feasting activities at the community mound and village centers.

The available information on the Nawi haia ina site rims, however, indicates that more than 75 percent have rounded lips; the others have flat lips, not including the one rim tab (Table 3). Almost 88 percent of the rims have a direct or vertical wall profile, another 7.5 percent have everted or out-flaring profiles, and only five rims from plain bowls and an engraved fine ware vessel have inverted rim profiles. Three other vessels have distinctive rim peaks.

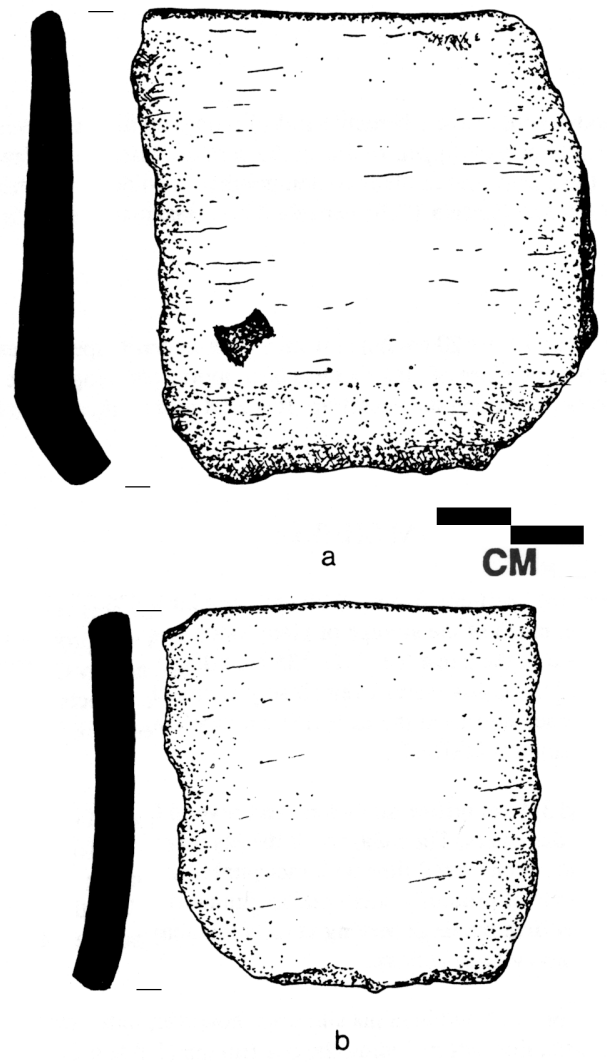

Figure 14. Plain bowl and carinated bowl rim sherds from the Nawi haia ina site. Provenience: a, Unit 28, 20-30 cm; b, Unit 35, 10-20 cm. 
Table 3. Rim attributes of the Nawi haia ina site ceramic vessel sherds.

\begin{tabular}{|c|c|c|c|c|}
\hline Attribute & Plain rim & Utility ware rim & Fine ware rim & $\mathrm{N}$ \\
\hline \multicolumn{5}{|l|}{ Rim profile } \\
\hline Direct & $87.2 *$ & 85.4 & 95.0 & 95 \\
\hline Everted & 4.3 & 14.6 & - & 8 \\
\hline Inverted & 8.5 & - & 5.0 & 5 \\
\hline Sub-total & 47 & 41 & 20 & 108 \\
\hline \multicolumn{5}{|l|}{ Lip } \\
\hline Rounded & $67.4^{*}$ & 66.2 & 66.7 & 127 \\
\hline Rounded-ext. folded & 6.5 & 10.3 & 3.3 & 14 \\
\hline Rounded-peaked & - & 2.9 & 3.3 & 3 \\
\hline Flat & 25.0 & 17.6 & 23.3 & 42 \\
\hline Flat-ext. folded & 1.1 & 1.5 & - & 2 \\
\hline Flat-int. folded & - & 1.5 & - & 1 \\
\hline Rim tab & - & - & 3.3 & 1 \\
\hline Sub-total & 92 & 68 & 30 & 190 \\
\hline
\end{tabular}

*percent

Among the utility ware rim sherds where the rim profile could be determined $(n=41)$, direct rims represent 85 percent of the sample, compared to 95 percent for the fine wares, and 87 percent for the plain rims. A significant percentage of the utility ware jars have everted rims (14 percent), and none of the fine wares and only two of the plain rims had such a rim treatment. Only one of the lips of the fine wares ( 3 percent) has been exterior folded, but the exterior folding of lips is much more common in the utility wares (11.8 percent), and plain vessels (7.6 percent). The exterior folding of vessel lips is a form of lip treatment commonly noted on cooking vessels in Middle and Late Caddo ceramic assemblages in the region, along with everted or outflaring rims. These forms of rim and lip treatment on cooking vessels would have facilitated the stirring of vessel contents, as well as the pouring and emptying of those contents into serving vessels or onto trash middens. Plain rims are from vessels with straight walls and rounded lips, most likely undecorated bowls and/or carinated bowls.

The most common decorated rim sherds have either incised (29 percent), engraved (27.1 percent), tool punctated (17.8 percent), and incised-punctated (11.6 percent) elements (see Table 2). Along with a few examples of cane punctated, lip notched (a rare but notable Middle and Late Caddo period vessel lip treatment in the Angelina, Sabine, and Big Cypress drainages of northeastern Texas), brushed, and brushed-punctated rims, the utility ware rims comprise 71 percent of the decorated rim assemblage. The engraved rim sherds are from fine wares, and these represent only 29 percent of the decorated rim sherds. This frequency is roughly similar to the proportion of fine ware sherds (including engraved and slipped rim and body sherds) in the site assemblage as a whole (22.4 percent), but the over-representation of decorated fine ware rims to fine ware body sherds ( 29 percent : 22.4 percent) compared to the relative proportions of the utility ware rim and body sherds ( 71 percent : 77.6 percent) indicates that the fine ware vessels were more likely to be decorated only on the rim, while many of the utility ware vessels (incised-punctated, cane punctated, incised, brushed, and tool punctated) were decorated on both the rim and the vessel body. Fingernail punctated ( $0: 49$ rim/body ratio), brushed (1:17), and brushed-punctated (1:11) decorative elements are much more prevalent on the body of utility ware vessels. Overall, the 
relative frequencies of decorated rim vs. decorated body sherds together clearly indicate that the ceramic assemblage from the Nawi haia ina site is dominated by utility ware vessels, and also that plain rimmed vessels are common.

\section{Base Sherds}

There are 108 base sherds from apparently flat, disk-shaped vessel bases in the assemblage, and 50 were included in the detailed sherd analysis sample. The thickest base sherds are from the larger and sturdy utility ware vessels (mean thickness of $11.65 \mathrm{~mm}, \mathrm{n}=25$ ), while the smaller and thinner-walled fine wares have bases that are on average almost $2 \mathrm{~mm}$ thinner (mean average of $9.76 \mathrm{~mm}, \mathrm{n}=16$ ); there is a clear bi-modality in base thickness between these two wares, with a range of 9.3-10.2 $\mathrm{mm}$ for the fine wares and 11.0-15.2 $\mathrm{mm}$ for the utility wares. The thickest base sherds must have come from some very substantial-sized vessels.

The base sherds are primarily from vessels fired in a reducing environment (78 percent), which is the case for both the decorated utility wares and fine ware sherds (see below), with the highest proportion of base sherds being from vessels that were then cooled in a high oxygen environment ( 62 percent), which is consistent with their coming from broken utility ware vessels.

A number of base sherds (42 percent) have been smoothed on their exterior surface, perhaps to facilitate their use and/or storage on flat surfaces. Another 26 percent have been smoothed on the interior, and these are probably from cooking vessels.

The base sherds are overwhelmingly tempered with grog ( 90 percent). Another 8 percent have only bone temper-and these may be from fine wares - and 2 percent have crushed rock or grit temper.

\section{Temper and Paste Comparisons}

The ceramic assemblage from the Nawi haia ina site is distinctive because of the very high percentage of grog (crushed burned/fired clay) employed for tempering of ceramic vessels, both in the fine wares and utility wares (see below). There are 31 different temper-paste combinations in the vessel sherds (including a few sherds $[n=5]$ with no added temper ${ }^{1}$ ), indicating the existence of diverse traditions among the Caddo potters at the site in the kinds of temper and paste that were deemed suitable and functional for the manufacture of utility ware and fine ware vessels.

About 11 percent of the vessel sherds do not have grog temper (Table 4). These include 1.3 percent that have only crushed pieces of hematite, another 7.4 percent have burned bone added to the paste, 2.3 percent have hematite and burned bone aplastics, and 0.1 percent have small rounded pieces of sandstone or grit; finally, about 31 percent of the vessel sherds have a sandy paste. There are significant differences in temper usage between the plain ware, utility ware, and fine ware sherds, and the possible significance of these differences are discussed below.

Table 4. Temper classes by ceramic wares at the Nawi haia ina site.

\begin{tabular}{lllll}
\hline Temper Class & $\begin{array}{l}\text { Plain rim } \\
\text { base }\end{array}$ & Plain body & Utility ware & Fine ware \\
\hline grog & $33.3^{*}$ & 31.9 & 27.4 & 39.1 \\
grog-SP & 16.7 & 13.9 & 15.3 & 13.5 \\
grog-organics & 1.3 & 6.9 & 2.6 & 8.3 \\
grog-organics- & & 1.9 & 1.9 & 1.5 \\
SP & 1.3 & & &
\end{tabular}


Table 4. Temper classes by ceramic wares at the Nawi haia ina site, cont.

\begin{tabular}{|c|c|c|c|c|}
\hline Temper Class & $\begin{array}{l}\text { Plain rim } \\
\text { base }\end{array}$ & Plain body & Utility ware & Fine ware \\
\hline $\begin{array}{l}\text { grog-grit } \\
\text { grit }\end{array}$ & - & $\begin{array}{l}0.4 \\
0.2\end{array}$ & - & - \\
\hline $\begin{array}{l}\text { grog-hematite } \\
\text { grog-hematite- }\end{array}$ & 3.8 & 13.7 & 11.0 & 9.0 \\
\hline $\begin{array}{l}\text { SP } \\
\text { grog-hematite- }\end{array}$ & 7.7 & 5.0 & 9.8 & 6.8 \\
\hline $\begin{array}{l}\text { organics } \\
\text { grog-hematite- }\end{array}$ & 1.3 & 1.7 & 0.6 & 2.3 \\
\hline organics-SP & - & 1.9 & 0.2 & 1.5 \\
\hline grog-bone & 12.8 & 7.1 & 11.0 & 4.5 \\
\hline $\begin{array}{l}\text { grog-bone-SP } \\
\text { grog-bone- }\end{array}$ & 3.8 & 2.3 & 5.2 & - \\
\hline organics-SP & - & - & - & 1.5 \\
\hline organics & 1.3 & 0.6 & 0.6 & - \\
\hline $\begin{array}{l}\text { grog-bone- } \\
\text { hematite } \\
\text { grog-bone- }\end{array}$ & 2.6 & 1.5 & 1.7 & 0.8 \\
\hline $\begin{array}{l}\text { hematite-SP } \\
\text { grog-hematite- } \\
\text { bone-organics- }\end{array}$ & - & 0.2 & 0.6 & - \\
\hline $\mathrm{SP}$ & 1.3 & - & 0.2 & - \\
\hline $\begin{array}{l}\text { bone } \\
\text { bone-organics- }\end{array}$ & 2.6 & 3.8 & 4.5 & 6.0 \\
\hline SP & 1.3 & 0.4 & 0.9 & - \\
\hline bone-organics & 2.6 & 1.5 & 1.7 & 1.5 \\
\hline bone-SP & 2.6 & 0.6 & 0.9 & 0.8 \\
\hline $\begin{array}{l}\text { hematite } \\
\text { hematite- }\end{array}$ & - & 0.4 & 0.4 & - \\
\hline organics & - & 0.2 & 0.2 & 0.8 \\
\hline hematite-SP & - & - & 0.2 & 1.5 \\
\hline $\begin{array}{l}\text { hematite- } \\
\text { organics-SP }\end{array}$ & 1.3 & 0.4 & 0.4 & - \\
\hline $\begin{array}{l}\text { bone-hematite } \\
\text { bone-hematite- }\end{array}$ & - & 2.1 & 1.5 & - \\
\hline $\begin{array}{l}\text { bone-hematite- } \\
\text { SP } \\
\text { bone-hematite- }\end{array}$ & 1.3 & 0.2 & 0.4 & - \\
\hline organics-SP & - & - & 0.2 & - \\
\hline $\begin{array}{l}\text { bone-hematite- } \\
\text { organics }\end{array}$ & - & 0.8 & - & 0.8 \\
\hline SP & 1.3 & - & 0.4 & - \\
\hline none & - & 0.4 & - & - \\
\hline $\begin{array}{l}\text { Total Sherds } \\
\text { Analyzed }\end{array}$ & 78 & 476 & 464 & 133 \\
\hline
\end{tabular}

* percentage; $\mathrm{SP}=$ sandy paste 
The high frequency of grog-tempered pottery at the site was a deliberate attempt on the part of the Caddo potters to slow the oxidation process of the ceramic vessels during firing. This would have created darker-colored vessels in the reducing environment, while allowing them to be fired longer, producing a harder ceramic vessel (Rice 1987:354; Teltser 1993:532, 540). Since grog-especially finely crushed grog as seen in the fine wares - has expansion coefficients comparable to the coefficients of the clay paste, this would have further contributed to the ability of fired vessels to withstand heat-related stresses, as well as increasing its flexural strength (Rice 1987:362).

The addition of bone and hematite, the other principal aplastics (found in 11.7 percent and 26.7 percent of the sherds, respectively) would have made the clay more plastic and increased its strength or use-life. Not too surprisingly, then, the coarser bone and hematite temper was more abundant in the decorated utility wares (29.4 percent and 27.6 percent, respectively of these sherds have such temper additions) than they are in the decorated fine wares (15.8 percent bone and 23.3 percent hematite) (see Table 4). Hematite and bone temper was also more common in the plain rim, body, and base sherds than was the case for the fine wares, particularly in the case of bone temper in the plain rims (30.8 percent) and hematite ( 28.2 percent) in the plain body and base sherds.

Between 27.1-36.9 percent of the Nawi haia ina site sherds have a sandy paste (Table 5), suggesting the regular use of a sandy clay for vessel manufacture. The decorated utility wares had the highest proportion of sandy paste sherds, and this ware also have the highest proportions of crushed hematite and bone-tempered sherds in the assemblage (see Table 4). It is likely that the Caddo potters recognized that sandy clays held up better to heat-related stresses and helped with vessel porosity and thermal conductivity, probably from the repeated use of the utility ware vessels for cooking and heating foods and liquids (see Rice 1987, 1996). Furthermore, the relatively high amount of quartz sand in the paste of both the utility and fine wares is likely related to the Caddo potters better controlling the making and firing of harder and more durable decorated carinated bowls and bottles, as well as jars and plain bowls.

Table 5. Proportion of sherds with a sandy paste in the Nawi haia ina site ceramic assemblage.

Wares

Percentage of Sherds with Sandy Paste

Plain rim sherds

Plain body and base sherds

Decorated utility ware

Decorated fine ware
$35.9 \%$

$26.9 \%$

$36.9 \%$

$27.1 \%$

The use of hematite as a temper may have served the same purpose as feldspars, which are often found together in the paste of Caddo vessels (see Perttula 2000). The occurrence of fine grains of these minerals in the paste would have enhanced a vessel's ability to melt and fuse the paste constituents during firing, resulting in a dense, hard body and a reduced porosity (Rice 1987:96).

About 7.8-14.6 percent of the sherds from the Nawi haia ina site have charred organics in the paste, most notably the plain body, base, and rim sherds, but with a respectable percentage also seen in the fine wares (see Table 4). The presence of charred organics indicate that a certain proportion of vessels were not fired at high temperatures and/or not fired for a long duration, and thus the organic materials naturally present in the clay did not have a chance to be completely burned off during firing. 


\section{Firing Conditions}

The Caddo potters at the Nawi haia ina site fired the majority of the vessels in a reducing or low oxygen environment - possibly smothered in a bed of coals from a wood fire-as approximately 73 percent of the sherds as a group were fired in this way (Table 6). Most of them were subsequently cooled in a high oxygen environment, probably meaning that the fire-hardened vessel was removed from the fire to cool.

Table 6. Firing conditions of the ceramic sherds from the Nawi haia ina site.

\begin{tabular}{lllll}
\hline Firing Conditions & $\begin{array}{l}\text { Plain } \\
\text { rim }\end{array}$ & $\begin{array}{l}\text { Plain body/ } \\
\text { base sherds }\end{array}$ & $\begin{array}{l}\text { Decorated Utility } \\
\text { ware }\end{array}$ & $\begin{array}{l}\text { Decorated } \\
\text { Fine ware }\end{array}$ \\
\hline $\begin{array}{llll}\text { Oxidized* } \\
\text { Incompletely Oxidized }\end{array}$ & $\begin{array}{l}18.8^{* *} \\
6.3\end{array}$ & 11.3 & 12.8 & 8.4 \\
Reduced & 23.8 & 10.9 & 16.9 & 6.8 \\
Reduced, Cooled in a & 51.3 & 60.7 & 18.3 & 6.1 \\
High Oxygen Environment & 50.9 & 51.9 & 131 \\
\hline Total sherds & 80 & 476 & 460 & 65.6 \\
\hline
\end{tabular}

$*_{\text {oxidized }}=$ A (see Teltser 1993); incompletely oxidized = C, D, E, I-L; reduced = B; reduced but cooled in a high oxygen environment $=\mathrm{F}, \mathrm{G}$, and $\mathrm{H}$

** percentage

As a whole, 12 percent were fired in a high oxygen or oxidized environment, and the remainder (15 percent) were incompletely oxidized during firing. The dominance of reduced firing conditions in the sherd assemblage suggests that the Caddo potters successfully regulated firing and cooling temperatures for both utility wares and fine wares at the site, especially the fine wares.

The highest frequency of vessel sherds firing in a reducing environment, and either cooled in low or high oxygen environments, occurs among the fine wares, where 84.7 percent of the sherds were fired and cooled this way (see Table 6). These sherds also have the lowest percent of sherds fired in an oxidizing environment, or incompletely oxidized during firing, while the decorated utility ware ceramics have much higher percentages (29.7 percent) of sherds from vessels fired in an oxidizing environment or incompletely oxidized during firing; the plain sherds are intermediate between the two wares, indicating that both kinds of firing of vessels are represented among the plain sherd assemblage (see Table 6).

These data point to the conclusion that there were significant changes in how utility ware and fine ware vessels were fired, differentiating the two basic vessel classes (along with other attributes previously discussed or to be discussed below, such as the kinds of tempers used, the frequency of sandy paste sherds, and the frequency of burnished and exterior smoothed vs. interior smoothed sherds). The comparison of sherd firing conditions suggests that the fine ware vessel sherds were better made and better fired (i.e., in terms of regulating the firing temperature) - and probably fired longer in a low oxygen environment, with more control over the end product, and producing a harder ceramic - than the utility ware vessel sherds. The more heterogeneous firing conditions of the utility ware vessel sherds is probably a result of the multi-purpose nature of these vessel forms, as they were being used as cooking pots and containers, and as long as the porosity of the utility wares was not excessive, they did not need to be fired for as long a time as the harder fine wares to be quite serviceable over time without being subject to diminished strength from cumulative thermal fatigue as well as cracks and fractures. The same can be said for the rims from plain wares (see Table 6). 
The decorated utility wares have thicker rim and body walls than do the fine ware vessel sherds. This further supports the functional and technological differences between these wares as noted from an examination of temper and paste characteristics; firing conditions; surface treatment; and also supports the fact that there are meaningful stylistic differences between these two wares. The mean thickness of utility ware rims is $7.48 \mathrm{~mm}$, compared to only $6.27 \mathrm{~mm}$ for the decorated fine wares; plain rims are intermediate (mean thickness of $6.56 \mathrm{~mm}$ ). Plain bottle rims are only on average $5.63 \mathrm{~mm}$ in thickness, while lip notched vessels are $7.42 \mathrm{~mm}$ in mean rim thickness. The one vessel with a rim tab is $7.6 \mathrm{~mm}$ thick below the lip; the lip notched and rim tab vessels are comparable to the utility ware vessels in rim wall thickness.

Decorated fine ware body sherds, other than bottle sherds, average $6.70 \mathrm{~mm}$ in thickness, while the decorated utility ware body sherds are $7.78 \mathrm{~mm}$ in average thickness, about 16 percent thicker than the fine wares. The engraved bottle body sherds are the thinnest of the decorated wares, with a mean thickness of $6.44 \mathrm{~mm}$.

\section{Surface Treatment and Residues}

The ceramic assemblage at the Nawi haia ina site is fairly well preserved, and many of the plain and/or decorated sherds retain evidence of smoothing or burnishing on interior and/or exterior surfaces (Table 7). Among the decorated utility wares, almost 37 percent of the sherds have been smoothed on the interior surface, compared to less than 7 percent smoothed or burnished on exterior surfaces. This smoothing was done presumably to lower the permeability and increase the heating effectiveness of particular vessels (cf. Rice 1996:148), namely the utility ware vessels used for cooking. Less than 3 percent have remnants of organic residues on interior or exterior sherd surfaces, however. In better preserved Caddo ceramic assemblages, such as a set of whole vessels from the mortuary assemblage at the Mockingbird site (41TT550), more than 30 percent of the vessels had preserved organic residues or charred plant remains adhering to interior or exterior vessel surfaces, and at least 40-60 percent of the vessels had either smoothed, burnished, or polished interior or exterior vessel surfaces (Perttula 2000:Table 3).

Table 7. Surface treatment and residues on vessel sherds from the Nawi haia ina site.

\begin{tabular}{|c|c|c|c|c|c|}
\hline $\begin{array}{l}\text { Surface Treatment/ } \\
\text { Residues }\end{array}$ & $\begin{array}{l}\text { Plain } \\
\text { rim }\end{array}$ & $\begin{array}{l}\text { Plain body/ } \\
\text { base }\end{array}$ & $\begin{array}{l}\text { Decorated utility } \\
\text { ware sherds }\end{array}$ & $\begin{array}{l}\text { Fine ware } \\
\text { sherds }\end{array}$ & $\mathrm{N}$ \\
\hline smoothed, interior & $37.2^{*}$ & 37.6 & 36.7 & 30.8 & 419 \\
\hline smoothed, exterior & 39.7 & 48.9 & 5.8 & 33.1 & 335 \\
\hline scraped, interior & - & 0.8 & - & - & 4 \\
\hline scraped, exterior & 1.3 & 0.2 & - & - & 2 \\
\hline burnished, interior & 2.6 & 2.1 & 0.9 & 9.8 & 29 \\
\hline burnished, exterior & 5.1 & 7.8 & 1.1 & 27.8 & 83 \\
\hline polished, exterior & - & 0.2 & - & - & 1 \\
\hline $\begin{array}{l}\text { organic residue, } \\
\text { exterior } \\
\text { organic residue, }\end{array}$ & 1.3 & 0.2 & - & - & 2 \\
\hline interior & - & 1.9 & 2.4 & - & 20 \\
\hline Totals & 78 & 476 & 464 & 133 & 1151 \\
\hline
\end{tabular}

* percentage 
The decorated fine ware sherds from the Nawi haia ina site are more frequently smoothed on the exterior surface than the utility wares ( 33 percent compared to less than 6 percent) as well as more commonly burnished on either interior (30.8 percent) or exterior (33.1 percent) vessel surfaces. One black-slipped bottle sherd has been well polished on the exterior vessel surface (see Table 7). There is a roughly equivalent smoothing and burnishing of interior and exterior surfaces of the fine wares (not including the bottles, which have a roughened interior vessel body). The fine wares were not used for cooking purposes, but probably to serve and hold foods and liquids, and the smooth interior surfaces of such vessels would no doubt have been advantageous in the repeated use of such serving vessels. The exterior smoothing and burnishing seems to have been designed for stylistic and display purposes, creating a flat and lustrous surface well-suited to highlight the engraved and slipped exterior surfaces of the fine ware vessels.

The plain sherds represent an amalgam of utility ware and fine ware sherds in the assemblage. About 5-8 percent of the plain rim and body sherds are burnished on the exterior surface-a much lower frequency (5-7 times less frequent) than the fine wares-compared to only 2 percent of the interior vessel surfaces. Nevertheless, burnished surfaces on the plain rim and body sherds is 2-7 times more common than are burnished surfaces in the utility ware sherds (see Table 7). Between 37-49 percent of the interior and exterior surfaces of the plain sherds are smoothed, which is roughly comparable to the decorated fine ware sherds rather than the decorated utility ware sherds, as less than 6 percent of the latter are smoothed on the exterior surface. This information suggests that some of the plain wares were treated as fine wares-being well-smoothed and/or burnished - and probably were also used for the serving of foods and liquids.

\section{Ceramic Pipes}

In the midden area excavations, several bowl and stem sherds from Red River style (cf. Hoffman 1967) long-stemmed pipes were recovered. This sort of ceramic pipe is frequently found at ancestral Caddo sites occupied between ca. A.D. 900-1400. Such pipes and pipe sherds are common in residential contexts (i.e., 90 such sherds were found at the Oak Hill Village, see Rogers and Perttula 2004:287), as well as burial contexts, including at the Nawi haia ina site.

The pipes have small bowls ( $\mathrm{n}=3$ ) with direct rims and flat lips (Figure 15a); the bowl height on one is about $2.5 \mathrm{~cm}$. The one sizable rim had a $4.0 \mathrm{~mm}$ orifice diameter. The bowls have been tempered with grog, bone, and bone-hematite, and have 3.6-4.1 mm thick pipe walls. The exterior surfaces had been burnished or well-smoothed, and each of the pipe bowls had an interior organic residue from the plants (tobacco?) that were smoked in the pipe. Sherd cross-sections indicate that the pipes were either fired in a reducing environment $(n=1)$ or were incompletely oxidized during firing $(n=2)$.

There are four pipe stem sherds in the collection, and they are from at least three separate pipes based on differences in temper inclusions and firing conditions. Three are tempered with grog and the other has bone temper. All were fired in a reducing environment, but three of the four are from pipes that were subsequently cooled in the open air. The stems range from 3.9-5.4 $\mathrm{mm}$ in thickness. Estimated stem diameters range from 12.7-13.2 mm (see Figure 15c), with an interior stem hole diameter of $5.6 \mathrm{~mm}$. At the contemporaneous Oak Hill Village, pipes were on average a bit smaller and thinner, as mean stem diameters ranged from 9.61-12.03 $\mathrm{mm}$; mean hole diameters were 5.24-6.50 $\mathrm{mm}$; and wall thickness ranged from 2.80-3.50 mm (Rogers and Perttula 2004:Table 77). The majority of the pipes at the Oak Hill Village were assigned to the Graves Chapel and Haley varieties of Red River pipe, which occur in ca. A.D. 1200-1400 contexts on Caddo sites in the Red River valley (e.g., Hoffman 1967:10). Since the Haley variety of long-stemmed pipe tends to be thicker than the Graves Chapel variety, the few pipe stem sherds from the Nawi haia ina site are likely from the Haley variety. 


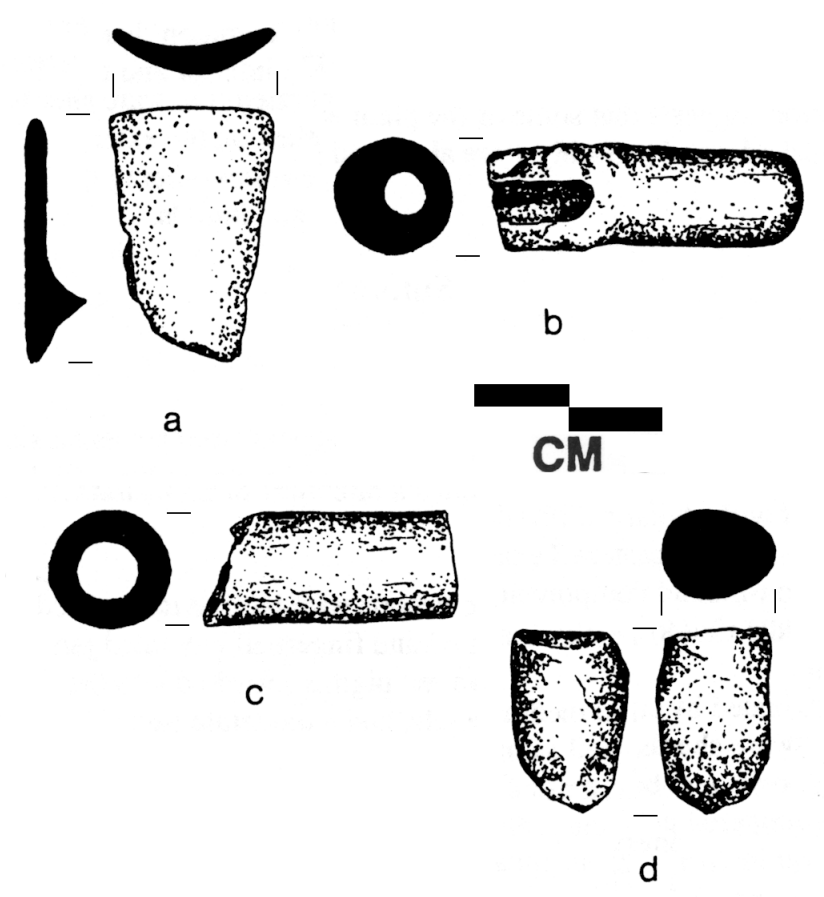

Figure 15. Ceramic pipe sherds and possible ceramic "foot" or support from the Nawi haia ina site.

Provenience: a, Unit 19, 40-50 cm; b, Unit 28, 0-10 cm; c, Unit 22, 40-50 cm; d, Unit 23, 30-40 cm.
Another indication that the ceramic pipes from the site are Haley variety examples is a pipe sherd from the butt end of a Red River style pipe (see Figure 15b); the butt end is that portion of the stem that is on the opposite side of the bowl from the mouth-piece. In this pipe sherd from Unit 28 $(0-10 \mathrm{~cm} \mathrm{bs})$, the butt end is flattened, which is also characteristic of Haley variety pipes. This particular stem sherd has bone temper, and was fired and cooled in a reducing environment. Thickness is $6.2 \mathrm{~mm}$, and the diameter of the pipe at the butt end is 10.8 $\mathrm{mm}$. The butt end itself extends $18 \mathrm{~mm}$ beyond the base of the stem/bowl attachment (see Figure 15b).

\section{Miscellaneous Clay Objects}

The miscellaneous clay objects from the Nawi haia ina site consist of two possible pieces of clay coils and one possible "foot" or pedestal support fragment. The possible clay coils are oxidized, rounded, and rolled coils of sandy clay. They are $25.5-28 \mathrm{~mm}$ in length, $16.1-19 \mathrm{~mm}$ in width, and $8.2-8.7 \mathrm{~mm}$ thick. Both pieces were found from $20-30 \mathrm{~cm}$ bs in Unit 30 and Unit 31.

The possible "foot" or pedestal fragment (see Figure 15d) is a rectangular and roughened piece of ceramics with a circular cross-section and a rounded base. Similar sherds, thought to be from Killough Pinched jars (Suhm and Jelks 1962:Plate 46a-c), have been recovered from the nearby and contemporaneous Oak Hill Village (41RK214) (see Rogers and Perttula 2004:Table 79).

\section{Regional Ceramic Comparisons}

Ceramic sherd vessel data from a series of generally contemporaneous sites in the mid-Sabine and Angelina River basins (Figure 16) allow for ceramic comparisons to be made with the ceramic assemblages from the Nawi haia ina site. The purpose is to look for ceramic stylistic affiliations between the site and other well-known Caddo sites, with an eye to identifying possible social relationships that may have existed between Caddo groups in the region.

There are a number of analyzed ceramic assemblages in the mid-Sabine River and upper Angelina River basins that represent distinctive Middle Caddo period ceramic traditions with similarities to the Nawi haia ina site assemblage (see Dockall et al. 2008; Dockall and Fields 2011; Fischbeck et al. 2015; Gadus et al. 2006; Heartfield, Price, and Greene, Inc. 1988; Perttula 2001, 2008, 2014; Perttula and Nelson 2003; Rogers and Perttula 2004). Where radiocarbon dates have been obtained from archaeological deposits at these sites they indicate that the Caddo assemblages date from ca. A.D. 1150 to ca. A.D. 1450, and perhaps a bit later at a few sites in the mid-Sabine River basin (i.e., 41HS573 and 41HS588, see Dockall et al. 2008; Gadus et al. 2006). 


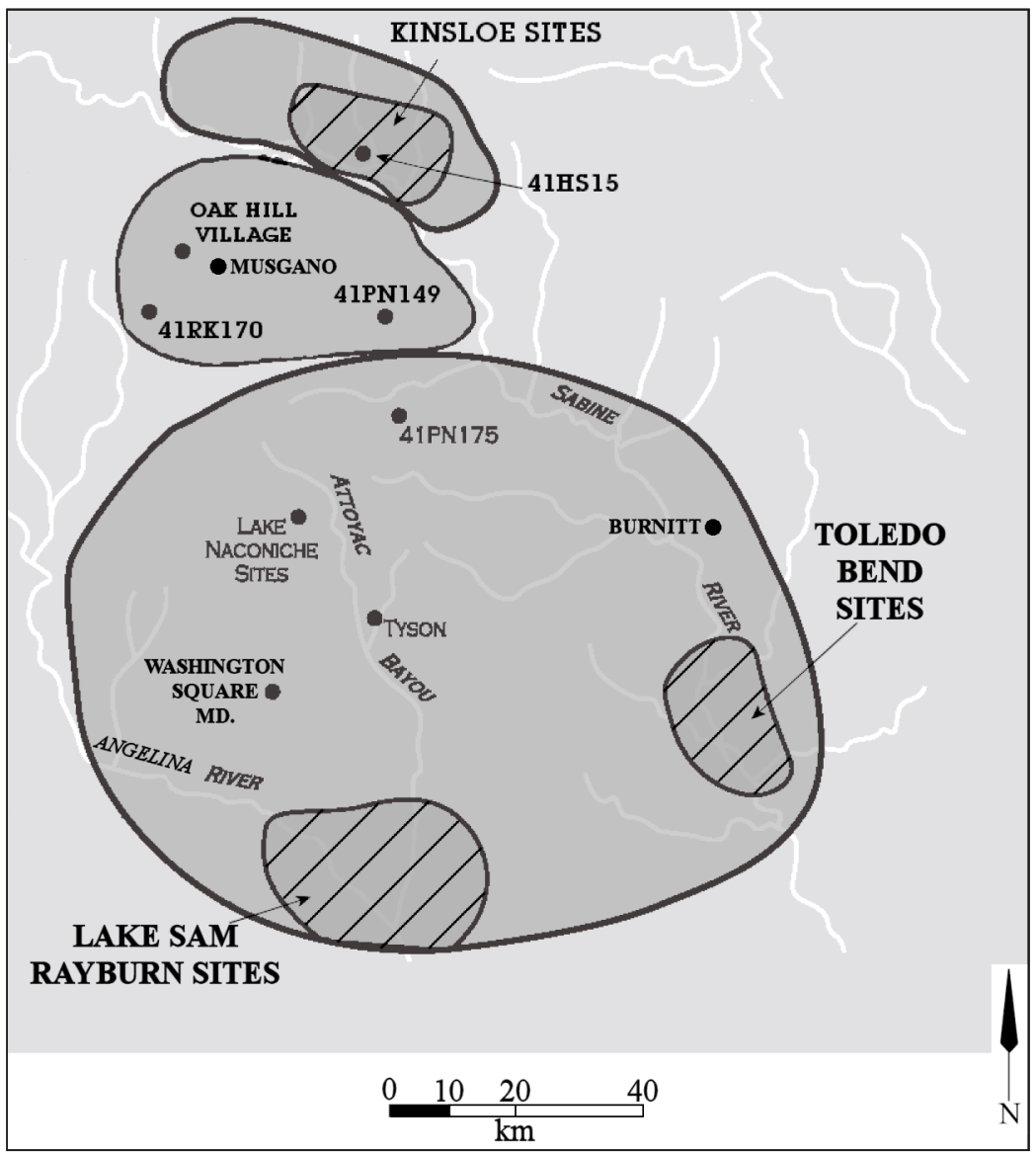

Figure 16. Ancestral Caddo sites in East Texas and Northwest Louisiana mentioned in the text, including Kinsloe phase, Toledo Bend Reservoir, and Lake Sam Rayburn sites.

In general, these ceramic assemblages are dominated by decorated utility wares, including vessels with incised, incised-punctated, and punctated decorative elements primarily from pre-A.D. 1300 contexts, and then later the decorated utility wares in sites begin to be dominated by sherds from brushed vessels, leading to much lower percentages of other kinds of decorated utility wares as well as lower proportions of fine wares. Assemblages where sherds from brushed vessels comprise more than 40 percent of the decorated sherd assemblages are also those where fine wares account for less than 13 percent of the overall assemblages; this group of assemblages does not include the Nawi haia ina site, as well as the Oak Hill Village site (Rogers and Perttula 2004). Red-slipped sherds account for less than 1 percent of the decorated sherds in all these assemblages, and only 0.3 percent of the decorated sherd assemblage at the Nawi haia ina site.

Washington Square Paneled sherds are present in certain generally contemporaneous sites in the mid-Sabine River basin. This includes 41HS573 (Gadus et al. 2006:Figure 4-12), 41HS574 (Gadus et al. 2006:Figure 4-29), and 41HS718 (Gadus et al. 2006:Figures 4-40 and 4-43) in the vicinity of the Pine Tree Mound site (41HS15). Another distinctive fine ware decorative element found in these mid-Sabine River basin assemblages is the engraved rattlesnake motif. Sherds with this motif have been found at the Oak Hill Village (41RK214) (Rogers and Perttula 2004:Figures 91p and 92), 41RK242 (Perttula 2001), and 41HS74 (Heartfield, Price, and Greene, Inc. 1988:Figure 6-16). 
Proportional trends in decorative elements, along with a series of calibrated radiocarbon dates and date ranges, also indicate that by ca. A.D. 1450 and after, mid-Sabine River basin sites have decorated sherd assemblages where more than 60 percent of all the decorated sherds have brushed decorative elements on rim and/or body sherds (see Fields and Gadus 2012; Perttula 2015). In the latest group of sites in these assemblages, between 65.8-66.7 percent of all the decorated sherds have brushed elements, either as the sole decorative element, or in association with appliqued, incised, or punctated elements. Ceramic assemblages that appear to predate A.D. 1450 fall into what are suggested to represent three temporally sequent assemblages with (1) between 42.9-51.2 percent brushed sherds; (2) 28.7-47.7 percent brushed sherds; and (3) 15.5-20.3 percent brushed sherds (Perttula 2014:Table 13). Sherds with brushed-incised and brushed-punctated decorative elements also appear to be most common in these pre-A.D. 1450 assemblages. The very low percentage of brushed sherds (5.0 percent) at the Nawi haia ina site (41RK170) in the upper Angelina River basin suggests that either the ceramic assemblage there is part of a different Caddo ceramic tradition than the ceramic tradition present in the mid-Sabine River basin Caddo sites, or that much of the ceramic assemblage at the site is associated with the cal. A.D. 1185-1270 occupation rather than the cal. A.D. 1297-1410 occupation.

To the east of the Nawi haia ina site by ca. $20 \mathrm{~km}$ (see Figure 16), the ceramic assemblage from the Tom Moore site (41PN149) on Irons Bayou can be distinguished in several respects from those to the south and west. Haskins and Walters (2001:59) suggest that the site has a Middle Caddo period component, but the single radiocarbon date (on corn) has a calibrated 2-sigma C14 age range of A.D. 1444-1649, suggesting instead that it is generally contemporaneous with Late Caddo period ceramic components. Approximately 24 percent of the sherds have bone temper, but only as secondary inclusions along with grog and grit (i.e., probably crushed hematite). Brushed sherds comprise only 21 percent of the decorated sherds $(n=300)$, and only 24 percent of the utility wares. More common utility wares are sherds with punctated (35 percent of the utility wares), incised (26 percent), and incised-punctated (13 percent) decorative elements. These proportions are similar to the Nawi haia ina and Oak Hill Village assemblages. Fine ware sherds comprise only 10.3 percent of the decorated sherds at the Tom Moore site, compared to 22.0 percent at the Nawi haia ina site and 11.3 percent at Oak Hill Village. The body sherds have cross-hatched filled panels, opposed lines, cross-hatched circles with rays, or pendant triangles, while the rims either have horizontal lines or a hatched zone or ladder element (Haskins and Walters 2001:53).

The Oak Hill Village site is a substantial $12^{\text {th }}$ to mid- $15^{\text {th }}$ century Caddo settlement on Mill Creek (Rogers and Perttula 2004), a tributary stream in the Sabine River basin, about $15 \mathrm{~km}$ northwest of the Nawi haia ina site (see Figure 16). Its ceramic sherd assemblage is grog-tempered, although 17 percent also have bone temper and 45 percent have hematite temper; most of the sherds are also from vessels with a sandy paste (Rogers and Perttula 2004:273).

The large decorated sherd assemblage $(n=3955)$ is about 88 percent from utility wares, and the remainder from engraved (11 percent) and red-slipped ( 0.8 percent) fine wares. The principal utility wares have punctated (40.5 percent), incised (20.5 percent), brushed (19.8 percent), and incisedpunctated ( 9.7 percent) decorative elements. The frequency of punctated sherds at the Oak Hill Village site is considerably more proportionally than has been documented at the Nawi haia ina site (14.0 percent). About 1.6 percent of the utility wares have appliqued elements, including appliqued ridges, fillets, and nodes (Rogers and Perttula 2004:Table 58). There is a lip-notched rim in the assemblage, as there are at the Nawi haia ina site. In addition to two body sherds with engraved rattlesnake motifs (Rogers and Perttula 2004:Figures 91p and 92), there are a variety of other distinctive and fairly wellrepresented engraved elements in the Oak Hill Village fine wares, including multiple vertical engraved lines, curvilinear engraved lines with excised triangles, hatched and cross-hatched triangles, narrow zones filled with hatched or cross-hatched lines, broad hatched zones, scrolls and semi-circles, and circles (Rogers and Perttula 2004:Figures 90f, h, n-o and 91b-h, 1-o). The broad and narrow hatched and cross-hatched zones and triangles are also seen in the Murvaul Creek site fine wares (see Perttula 2015), as well as other contemporaneous sites in the region. 
The Musgano site (41RK19) is a ca. 14-15 ${ }^{\text {th }}$ century A.D. Caddo settlement on Martin Creek (Clark and Ivey 1974; Perttula 2014), a northward-flowing tributary to the Sabine River, and ca. $15 \mathrm{~km}$ northeast of the Nawi haia ina site (see Figure 16). Calibrated radiocarbon dates range from A.D. 1344-1455. The ceramic sherd assemblage $(n=7803)$ is overwhelmingly grog-tempered (92 percent), with a low percentage of sherds with bone as the primary or secondary temper inclusion (11 percent) and sherds with a sandy paste (7 percent), similar to the Nawi haia ina ceramic assemblage.

Utility wares comprise about 91 percent of the decorated sherds from the Musgano site, with the fine wares (engraved and red-slipped) the remainder. Among the utility wares, almost 40 percent are from vessels that have brushing marks (not including another 7 percent that have brushed-punctated, brushedincised, and brushed-appliqued decorative elements), with another 20 percent with punctated decorations, 18 percent incised, and 12 percent incised-punctated (Perttula 2014). In some respects, these proportions are not similar to decorated ceramics from the Nawi haia ina site. The engraved fine wares, and the incisedpunctated variant of Washington Square Paneled sherds at the Musgano site, are not stylistically similar to the post-A.D. 1450 fine wares documented from the Pine Tree Mound community (see Fields and Gadus 2012) a few miles to the north on another tributary of the Sabine River (see Figure 16). Instead they are more like ceramic assemblages on Middle Caddo period (ca. A.D. 1200-1450) sites in the mid-Sabine and Angelina River basins (cf. Gadus et al. 2006; Hart 1982, 2014; Perttula and Nelson 2003; Walters 2003, 2004, 2008), and it is likely that various Caddo communities in these areas had close social and cultural ties and established networks of contact and cultural transmission of ideas and practices.

Among the fine ware sherds, the rims from engraved carinated bowls and bowls in the Musgano assemblage feature circular and curvilinear elements, sets of diagonal lines, and rims with horizontal lines and various associated elements. These include curvilinear and diagonal lines, zig-zag lines, excised punctations, hatched pendant triangles, cross-hatched zones (possibly triangular elements), and hatched oval-shaped elements. The rims with horizontal engraved lines and associated elements comprise 72.9 percent of the engraved rims from carinated bowls and bowls. None of the rims have scroll elements, which feature so prominently in post-ca. A.D. 1450 assemblages in the mid-Sabine River basin (e.g., Fields and Gadus 2012). Furthermore, none of the engraved rims from the Musgano site can be identified with a currently defined fine ware type in the current East Texas ceramic typology, which is a common situation for Middle Caddo period fine wares in this part of East Texas because of the stylistic diversity that is characteristic of these ca. A.D. 1200-1450 ceramic assemblages. The decorative elements on the engraved carinated bowl and bowl sherds from the Musgano site are as diverse as the recognizable elements on the rims; none of the sherds are part of a scroll motif. The more recognizable and distinctive elements include circles and hatched circles, narrow hatched and cross-hatched zones and cross-hatched triangles, curvilinear hatched and cross-hatched zones as well as hatched pendant triangles, horizontal engraved lines with hatched and cross-hatched pendant triangles, and sets and arcs of curvilinear lines. Many of the same engraved elements are present in the nearby and generally contemporaneous Oak Hill Village (41RK214) ceramic assemblage (Rogers and Perttula 2004:217-222) as well as other mid-Sabine River basin sites. These include closely-spaced curvilinear lines; hatched and cross-hatched triangle elements; narrow hatched and cross-hatched zones or ladders (the most common engraved decorative element at the Oak Hill Village); and circle elements and concentric circles with pendant triangles.

Engraved sherds comprise almost 24 percent of the engraved fine wares from the Musgano site. There is one engraved bottle rim sherd from a Hickory Engraved bottle that has a series of horizontal lines encircling the neck. The decorative elements on the bottle bodies are diverse, with circles, hatched and cross-hatched ovals and narrow panels and zones, as well as possible canebrake rattlesnake elements from Nacogdoches Engraved vessels. Engraved canebrake rattlesnake motifs on bottles has been found in ceramic assemblages in at least 17 Middle and Late Caddo period sites in the Big and Little Cypress Creek, mid-Sabine, Red River, and Angelina River basins in East Texas (Walters 2006; Gadus 2013). 
Pipe sherds at the Musgano site are from the distinctive L-shaped elbow pipes (Clark and Ivey 1974:Figure 13o-p). This style of elbow pipe has also been recovered at several other $13^{\text {th }}-15^{\text {th }}$ century sites in the middle and upper reaches of the Sabine River basin, including at the Oak Hill Village (41RK214, Rogers and Perttula 2004), Redwine (Walters and Haskins 1998), 41WD244 (Perttula et al. 2007), 41HS574 (Gadus et al. 2006:Figure 4-34), and Taddlock (41WD482, Bruseth and Perttula 1981) sites, and at the Beech Ridge site (41NA242) at Lake Naconiche in the Angelina River basin (Perttula 2008). No such elbow pipe sherds are present at the Nawi haia ina site.

The Pine Tree Mound site (41HS15) is an important Caddo ceremonial and civic center on Potters Creek that was occupied from the $14^{\text {th }}$ century A.D. to the mid-1600s (Fields and Gadus 2012), a tributary to the Sabine River, and about $40 \mathrm{~km}$ northeast of the Nawi haia ina site (see Figure 16). It has a large assemblage of analyzed ceramic vessel sherds $(n=9874)$ from village areas and the core area (Gadus and Fields 2012:Table 6.15). Approximately 44 percent of the sherds are tempered solely with grog, another 40 percent are tempered with grog and bone, and the remaining 16 percent are tempered solely with bone. The use of bone as a temper is considerable (60 percent of the analyzed sherds), as has been pointed out previously to be the case in a number of other sites in this East Texas region, but not the Nawi haia ina, Oak Hill Village, and Musgano sites (9.7-16.8 percent bone-tempered). Other generally contemporaneous sites (i.e., with calibrated radiocarbon dates that range from as early as the late $12^{\text {th }}$ century to the mid- $17^{\text {th }}$ century) in this area examined by Gadus et al. (2006), Dockall et al. (2008), Dockall and Fields (2011), and Fischbeck et al. (2015) suggest that the use of bone temper increases through time, as sherds with bone temper in earlier Middle Caddo components at 41HS231, 41HS574, 41HS844, 41HS846, and 41RK693 account for only 10-37 percent of the vessel sherd assemblage, but this proportion increases to more than 50 percent at post-mid- $15^{\text {th }}$ century sites/components at 41HS573, 41HS843, 41RK557, and 41RK674.

Among the decorated sherds $(n=6620)$, almost 90 percent are from utility ware vessels, with fine wares (engraved and red-slipped sherds) accounting for only 10.2 percent of the sherds (Gadus and Fields 2012:Table 6.15). Most of the utility ware sherds are from vessels with brushing -84 percent of the utility wares and 76 percent of all the decorated sherds - as the main decorative technique, followed by sherds with incised (11.5 percent of the utility wares), punctated/pinched ( 3 percent), appliqued (1 percent), and ridged ( 0.9 percent, Belcher Ridged). Secondary decorative techniques feature appliqued $(n=313)$, punctated $(n=586)$, and pinched $(n=14)$ decorations. The main decorative elements in the assemblage include rectilinear lines, horizontal brushing, vertical brushing, curvilinear lines, cross brushing, diagonal brushing, and lines of punctations, while secondary decorative elements include hatching, lines of punctations, and linear appliqued fillets. In most cases, these main and secondary decorative elements in the Pine Tree Mound ceramic sherd assemblage are quite comparable to the utility wares from other post-A.D. 1450 sites in the region, especially with respect to the brushing elements, lines of punctations, and linear appliqued elements, and Pease Brushed-Incised jar sherds are common. Utility wares at other nearby sites are also dominated by sherds from Pease Brushed-Incised vessels, as well as from Bullard Brushed, Maydelle Incised, and Harleton Appliqued vessels (Gadus et al. 2006; Dockall et al. 2008; Fischbeck et al. 2015), and brushing comprises more than 50 percent of the decorated sherd assemblages. Where the Pine Tree Mound site, as well as other nearby post-A.D. 1400 sites, ceramic sherd assemblages are most divergent are in the fine wares. The Pine Tree Mound site fine wares are dominated by sherds from Titus phase vessels with scroll motifs, slanted scrolls, circles, pendant triangles, and SZ elements from Ripley Engraved and Wilder Engraved carinated bowls and bottles, along with sherds from Simms Engraved and Taylor Engraved vessels, none of which are present in the Nawi haia ina site fine wares or other sites within a ca. $20 \mathrm{~km}$ radius of the site (see Figure 16).

The Pine Tree Mound site is part of a local community (covering ca. $2400 \mathrm{~km}^{2}$ ) centered on the Sabine River and the Hasinai Trace in East Texas. Sites identified in the community generally date after ca. A.D. 1400 and have high percentages of brushed ceramics and a low ratio of plain to decorated sherds (Fields and Gadus 2012:655; see also Gadus et al. 2006; Dockall et al. 2008; Dockall and Fields 2011; Fischbeck et al. 2015). Several sites discussed herein are included in this community by Fields and 
Gadus (2012:661) - among them, Oak Hill Village and Musgano. The stylistic diversity apparent in the Titus phase engraved fine wares - and the common manufacture and use of Ripley Engraved vesselsfrom the Pine Tree Mound site are not duplicated in the Nawi haia ina, Musgano, and Oak Hill Village site fine wares.

The principal ancestral Caddo component at the Murvaul Creek site (41PN175) dates from cal. A.D. 1457-1513 (McKee et al. 2015); the site is ca. $40 \mathrm{~km}$ southeast of the Nawi haia ina site (see Figure 16). The ceramic vessel sherd assemblage (Perttula 2015) exhibits a considerable reliance on burned and crushed bone as a temper for the manufacture of plain wares, utility wares, and fine wares; the firing of plain wares, utility wares, and fine wares primarily in a reducing or low oxygen environment; a very high proportion ( $>93$ percent) of utility ware sherds among the decorated vessel fragments in the assemblage; and the utility ware sherds are dominated by those with brushed rims and bodies ( 62.5 percent of the 1698 decorated sherds in the assemblage), or with rim and body sherds (6.9 percent of the decorated sherds in the assemblage) with brushed marks in combination with other decorative methods (punctations, incised lines, appliqued elements). The few fine ware sherds (from carinated bowls, compound bowls, and bottles) are characterized by geometric decorative elements, as well as narrow hatched and cross-hatched zones and triangles. Overall, the Murvaul Creek site ceramic assemblage best shares stylistic and technological features (i.e., mainly the common use of bone temper in vessel manufacture) with other known and generally contemporaneous sites in the mid-Sabine and Angelina River basins, especially with sites in the Angelina River basin and northward-draining tributaries to the Sabine River.

There are several Lake Naconiche sites in the Attoyac Bayou basin that share stylistic and technological similarities to the Nawi haia ina site assemblage. These sites are on a tributary to the Attoyac Bayou, about $35 \mathrm{~km}$ to the southeast (see Figure 16). The Tallow Grove (41NA231), Foggy Fork (41NA235), and Beech Ridge (41NA242) sites date from the $13^{\text {th }}$ century to the late $15^{\text {th }}$ century, while the principal component at the Naconiche Creek site (41NA236) dates to the mid-16 $6^{\text {th }}$ century and after (Perttula 2008:213-220). The first three Caddo sites have ceramics that are most commonly tempered with grog (90.6-96.5 percent), but between 27.4-38.3 percent also have had burned bone added as a temper, along with crushed hematite (8.5-11.9 percent); between 8.5-18.8 percent of the sherds are from vessels with a sandy paste, indicating common use of naturally sandy clays for vessel manufacture, as is also the case at the Nawi haia ina site.

Sherds from utility wares dominate the decorated sherds $(n=3160)$ from the Tallow Grove, Foggy Fork, and Beech Ridge sites, particularly sherds with brushed (31.3-42.5 percent), incised (14.9-23.1 percent), punctated (7.9-21.1 percent), and incised-punctated (4.1-9.0 percent) decorative elements. Fine wares-including sherds with red-slipped, engraved-punctated (from Washington Square Paneled vessels), and engraved elements - account for only 9.3-17.8 percent of the decorative sherd assemblage, and the proportion of fine wares appears to decrease after the early $15^{\text {th }}$ century (Perttula 2008). Many of the distinctive engraved elements in the fine wares from these Lake Naconiche sites are shared with those identified at the Nawi haia ina site, including triangles, hatched triangles, cross-hatched zones, curvilinear and vertical hatched zones, and hatched and curvilinear zones (see Perttula 2008:Figure 7-66).

Both the Tallow Grove and Beech Ridge sites have long-stemmed Red River pipe sherds, along with a platform pipe (at Tallow Grove) and an L-shaped elbow pipe (Beech Ridge) (Perttula 2008:Figures 7-77 and 7-80 to 7-82). Elbow pipe sherds are present in the ceramic assemblages from both the Beech Ridge and Foggy Fork sites, dating from probably post- $15^{\text {th }}$ century A.D. contexts.

At the later Naconiche Creek site, 28 percent of the sherds have bone temper, another 6.7 percent have hematite temper, and 82.7 percent have grog temper, either as the sole temper or in combination with bone and/or hematite. Almost 19 percent of the sherds are from vessels with a naturally occurring sandy paste. Almost 98 percent of the decorated sherds $(n=1060)$ from the site are from utility wares, 
and notable among them are sherds with brushing marks (70.1 percent), as well as brushed-incised (4.8 percent), brushed-punctated (1.9 percent), brushed-appliqued (1.8 percent), appliqued ( 0.4 percent), and appliqued-incised ( 0.2 percent) elements, which were uncommon decorative elements before the early $15^{\text {th }}$ century. These proportions are quite similar to the post-A.D. 1450 ceramic assemblages in the region, including Pine Tree Mound and the Murvaul Creek site.

The Tyson site (41SY92) is a $14^{\text {th }}$ to mid- $15^{\text {th }}$ century Caddo settlement on Attoyac Bayou (Middlebrook 1993, 1994, 1997), a tributary to the Angelina River, about $60 \mathrm{~km}$ southeast of the Nawi haia ina site (see Figure 16). Here, brushed sherds comprise about 38 percent of the decorated sherds $(\mathrm{n}=1862)$, and the brushing occurs as parallel and diagonal designs on bodies, and in conjunction with incised and punctated rows and panels from vessels and sherds identified as Karnack Brushed-Incised and Pease Brushed-Incised (Middlebrook 1994:26). Similar decorative treatments are noted at other sites in the region, but panels are more commonly made with appliqued ridges and fillets, and there are no appliqued sherds in the ceramic assemblage at Tyson. Incised-punctated sherds (mainly punctations in curvilinear incised zones) are relatively abundant at Tyson (Middlebrook 1997:39-40), and incisedpunctated sherds only account for 16.0 percent of the decorated sherds at the Nawi haia ina site.

Some of the engraved wares at Tyson have a distinctive S-shaped scroll element that has been classified as Tyson Engraved (Middlebrook 1994:Figure 3), and there are other sherds that have hatched fill zones that are similar to Nacogdoches Engraved (see Hart 1982, 2014). Other common engraved elements noted in the ceramics at the Tyson site and other contemporaneous Caddo sites in the Angelina River basin include circles, concentric circles, scrolls, circles with rays, ladders, narrow zones, and panels filled with hatching or cross-hatching, and pendant triangles (Middlebrook 1997:40). Engraved zones and panels with hatched or cross-hatched elements are one of the distinctive aspects of the fine wares at the Nawi haia ina site, but circles and scroll elements are conspicuously absent in the latter's fine ware assemblage.

At the Washington Square Mound site (41NA49), a $13^{\text {th }}$-mid- $15^{\text {th }}$ century mound center on a tributary to the Angelina River and ca. $56 \mathrm{~km}$ southeast of the Nawi haia ina site (see Figure 16), the ceramics are both grog and bone-tempered, with 71.6 percent of the sherds having either bone or grog-bone temper, very much not like the Nawi haia ina site ceramic assemblages. The utility wares are dominated by sherds from brushed vessels (61 percent) (Hart 1982, 2014; Perttula 2009). About 16 percent of the vessels from burials are also brushed (Hart 1982, 2014; Perttula et al. 2010). There are also a few brushed-punctated (6 percent) and brushed-incised (4 percent) sherds from Reavely Brushed-Incised jars at the Washington Square Mound site, as well as incised (13 percent), incised-punctated ( 4 percent), and appliqued ( 2 percent) decorative elements; these are not similar in proportions to the Nawi haia ina site ceramic assemblages.

The rare (8 percent of the decorated sherds) fine wares at Washington Square include a few Washington Square Paneled sherds and vessels, and engraved sherds and vessels primarily from Nacogdoches Engraved vessels; there are no Washington Square Paneled sherds in the Nawi haia ina fine wares. The engraved sherds have scrolls, concentric circles, and hatched and cross-hatched fill elements and zones (Hart 1982:Figure 3-4; Hart and Perttula 2010:Figures 5-9), as well as hatched triangles and narrow curvilinear cross-hatched zones (Perttula 2009:167 and Figure 19). One of the Nacogdoches Engraved vessels from Washington Square has a canebrake rattlesnake motif (Corbin and Hart 1998:Figure 31; Hart and Perttula 2010:Figure 8). This motif is found on vessels and sherds in two clusters in East Texas, a cluster of several sites in the mid- and upper Sabine River basin, not far from the Nawi haia ina site, and a larger number of sites farther away (ca. $100 \mathrm{~km}$ ) in the Big and Little Cypress Creek basins (Hart and Perttula 2010:Figure 2; Walters 2006). No engraved sherds with rattlesnake motifs were identified at the Nawi haia ina site, however.

The Salt Lick, Goode, and Bison, Area B sites at Toledo Bend Reservoir to the southeast of the Nawi haia ina site are heavily bone-tempered wares, and the utility wares (ranging from 953 to 2322 sherds per site, see Kelley 2006:Table 6-3) are well represented by sherds from both brushed (34-66 percent of 
the utility wares) and ridged (5-20 percent) vessels. Fine wares, engraved sherds only, comprise between 19-34 percent of the decorated sherds at the three sites, comparable in abundance to the fine wares at the Nawi haia ina site. The decorative styles on the engraved wares at these sites and the Burnitt site have strong links to Red River and mid-Sabine River sites (see Kelley 2006:55, 57, 60-61) but not to the engraved fine wares at the Nawi haia ina site.

The Burnitt site is a $16^{\text {th }}-17^{\text {th }}$ century Caddo site in the uplands on the east side of the Sabine River basin (Kelley 2006), about $90 \mathrm{~km}$ southeast of the Nawi haia ina site (see Figure 16). The ceramics $(n=3050)$ from the site are tempered almost exclusively with grog, but 22 percent are tempered with bone, less than is the case at the Nawu haia ina site; most of the sherds also have a sandy paste (83 percent). The utility wares comprise 88 percent of the decorated sherds, and fine wares (exclusively engraved sherds; there are no red-slipped sherds in the assemblage) only 12 percent, not much different than the ceramics at Nawi haia ina. However, the utility wares are dominated by sherds from vessels with either brushed ( 41 percent) or ridged ( 38 percent) decorations. The ridged pottery is identified as Belcher Ridged (Kelley 2006:55), an important utility ware in the Belcher phase, found in post-A.D. 1500 Caddo settlements in the Great Bend area of the Red River in Northwest Louisiana and Southwest Arkansas. As mentioned above, Belcher Ridged also occurs in varying frequencies in mid-Sabine River basin sites at Toledo Bend Reservoir (McClurkan et al. 1966; Woodall 1969). Kelley (2006:64) concluded that the Burnitt site, and other sites in the vicinity, "represent a local group whose ceramic tradition was distinct from Titus or Belcher in a number of ways. Certainly they had contact with both these regions..." No ridged pottery has been identified in the utility wares at the Nawi haia ina site, and it does not appear on stylistic grounds that the site had close stylistic or social relationships with these mid-Sabine River Caddo peoples or with more far-flung Caddo peoples living below the Great Bend of the Red River in Northwest Louisiana.

The post-15 $5^{\text {th }}$ century A.D. Walter Bell site at Lake Sam Rayburn (Jelks 1965) (see Figure 16) has a large decorated sherd assemblage $(n=4452)$. Utility wares comprise 96 percent of the decorated sherd assemblage, particularly sherds from vessels decorated with brushed (47 percent) and incised (40 percent) decorative elements (Perttula 2009:Table 18); at the Nawi haia ina site, only 5 percent of the decorated sherds are brushed and 25.6 percent have incised decorative elements. Unlike the Nawi haia ina site (22.3 percent in the site as a whole), fine wares are not common, accounting for only 4 percent of the decorated sherds at Walter Bell. Although not quantified by Jelks (1965), the sherds at the Walter Bell site were clay [grog]-tempered, but he does note that bone-tempered and sandy paste Caddo ceramics were also present in the assemblage.

This consideration of the Caddo ceramic technology (i.e., use of different tempers) and decorative styles documented in the ceramic vessel sherds at the Nawi haia ina site suggests that the closest affiliations of the Caddo groups that lived there from the late $13^{\text {th }}$ century onward into the $16^{\text {th }}$ century were with other Caddo communities living not far to the north and east in the Sabine River basin and the upper part of the Angelina River basin (Figure 17). These sites are not part of the Pine Tree Mound community in the Sabine River basin, although it is likely that additional work on other sites will show that this broad area of East Texas probably has several distinctive and more localized Caddo ceramic traditions during this lengthy time period. By tradition, I mean a single, coherent community of technological and stylistic practice specific to the peoples of a given region. This ceramic tradition is consistent with a broad unity in culture and material culture production, as well as a shared native history, one that presumably developed through centuries of intermarriage, trade, transmission of learning, and other kinds of reciprocal relationships. This same broad area of East Texas was occupied in historic times by numerous Caddo groups that were affiliated with the Hasinai Caddo (Bolton 1987; Swanton 1942), including the Nasoni, Nadaco, Hainai, and Nacogdoche.

The Caddo settlers at the Nawi haia ina site shared a common ceramic heritage with other ancestral and historic Caddo groups living in a considerable part of East Texas. Generally speaking, sites in this 


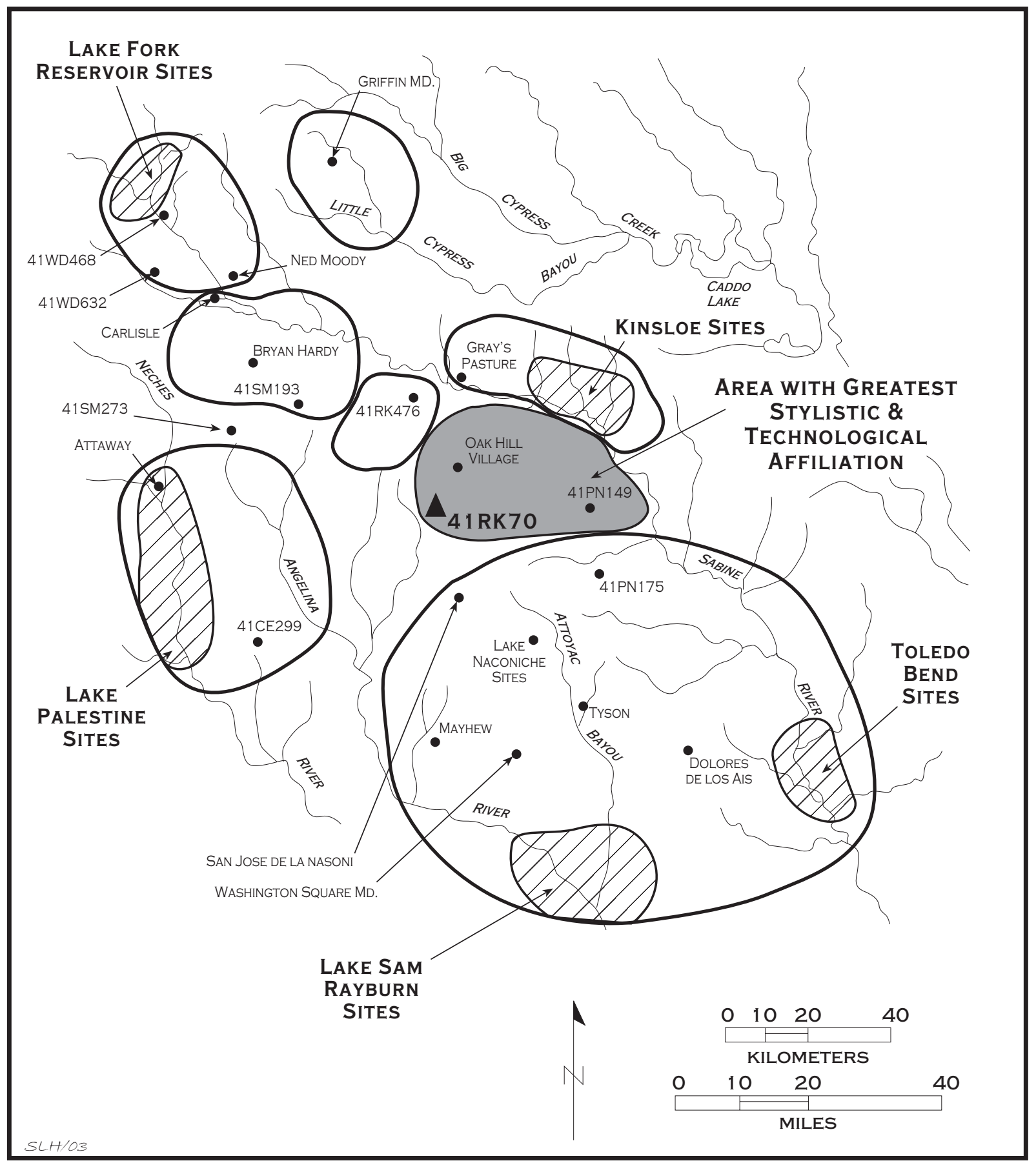

Figure 17. Different site and ceramic clusters of Middle Caddo sites in northeastern Texas, and the area with the greatest stylistic and technological affiliation with the Nawi haia ina site. Note the location of the Nawi haia ina site relative to that of the Oak Hill Village.

area have ceramic assemblages where brushing is almost always an especially important decorative component in the utility wares after ca. A.D. 1250, although not at the Nawi haia ina site and a few others, and the proportion of brushed pottery appears to increase through time after ca. A.D. 1400/1450. Fine wares are not common, and sherds from red-slipped vessels are exceedingly rare. Ceramics at some of these sites also have high proportions of burned bone temper, either as the sole temper, or in combination with other tempers; naturally sandy clays were frequently used in vessel manufacture. The 
sites with the closest affiliation to the Nawi haia ina site, however, tend to have only modest amounts of bone-tempered pottery (between 11.3-16.8 percent at the Musgano and Oak Hill Village sites, respectively). West in the upper Neches River basin, north in the Big Cypress Creek basin, and northwest in the upper Sabine River basin, by contrast, grog was much the preferred temper between ca. A.D. 1300 and 1700 .

\section{Summary and Conclusions}

The accidental discovery of human remains in a backhoe trench in the City of Henderson's Southside Wastewater Treatment Plant led to the archaeological investigations at the Nawi haia ina site (41RK170) and the recovery of a substantial ceramic vessel sherd assemblage in midden deposits and several ceramic vessels from funerary contexts (Perttula and Nelson 2003). That midden deposit accumulated periodically between cal. A.D. 1185-1410, based on a number of calibrated radiocarbon dates on organic remains in the midden. Beneath the midden, in the natural E-horizon sandy sediments, we uncovered evidence that the Nawi haia ina site was also occupied during the Woodland period, perhaps occupied at least twice, once around ca. 350-50 B.C. and then again sometime between ca. A.D. 200-700.

The Caddo that lived at the Nawi haia ina site lived in permanently occupied settlements, successfully grew maize and other cultigens (beans and squash), and lived in dispersed communities led by a social hierarchy of priests, civic leaders, and other elites. These leaders lived at the civic-ceremonial centers placed at key locations across the landscape-major river crossings, and at the intersection of trails and major foot paths. The closest civic-ceremonial center to the Nawi haia ina site is the Oak Hill Village, about 10 miles to the north (see Figure 17). This large village had a single earthen mound built and used in the $14^{\text {th }}$ century, during the Middle Village occupation there (Rogers and Perttula 2004).

This consideration of the site's ceramic technology and decorative styles suggests its closest affiliation is with other Caddo sites and communities in a ca. 35 x 20 mile area to the north, northeast, and east of the Nawi haia ina site (see Figure 17). The ancestral Caddo ceramic assemblage from the Nawi haia ina site appears to represent a component with stylistic affiliations to contemporaneous Caddo sites in the middle reaches of the Sabine River basin as well as to sites in the upper Angelina River basin in East Texas. The ceramic vessel sherds represent a non-mortuary and non-mound component, and as such, provides a rare view of the character of the ceramic assemblage in a Middle Caddo domestic context.

The assemblage is dominated by small to medium-sized ceramic vessels with incised and incisedpunctated decorations on utility ware sherds, as well as many tool punctated and fingernail punctated jars, engraved fine wares (carinated bowls and bottles, a number of which have red pigment worked into the design), the heavy use of grog-temper in the manufacture of pottery, the reduced firing of vessels, and a moderate use of bone and hematite as additional temper inclusions. The apparently hematite-rich clays that were used at the Nawi haia ina site have also been noted at other nearby and contemporaneous Caddo sites in the Oak Hill Mine area less than 10 miles to the north as well as other nearby sites (see Reese-Taylor et al. 2004; Perttula 2001; Haskins and Walters 2001). Brushed utility wares are relatively rare at the Nawi haia ina site, unlike most other sites in the region (see Figure 17), while engraved fine wares are apparently more common here, than at these other contemporaneous sites, which may simply reflect functional, intra-site, and/or temporal differences between them, but may hint that some of the Caddo social elite might have been living there, or at least were living in the near vicinity of the trash midden and probable house areas that were investigated during the project by Perttula and Nelson (2003).

Clear differences in temper and paste attributes, firing conditions, surface treatment, and vessel wall thicknesses - as well as the kinds of decorations placed on vessel rims and body surfaces - are apparent in the ceramic vessel sherds between the fine wares and the utility wares. These differences can be readily traced to different technological, functional, and stylistic decisions made by Caddo potters on how to make, fire, finish, and decorate ceramic vessels that were used in domestic tasks here, but were 
also used for ritual and ceremonial activities at the mound centers and community cemeteries, as well as in certain family cemeteries like the cemetery at the Nawi haia ina site.

\section{End Note}

1. The five sherds without temper inclusions may represent the only ceramics from the Nawi haia ina site that can be associated with the Woodland period occupation. Non-tempered and sandy paste ceramics are present in Woodland period components in the middle part of the Sabine River basin (see Rogers et al. 2001) as well as in the Angelina River basin (see Jelks 1965). The five sherds in question were found on the surface and between $0-30 \mathrm{~cm}$ bs in the trench unit excavations; the latter context, however, has been interpreted as midden deposits associated with the Middle Caddo occupation at Nawi haia ina.

Three of the sherds have a sandy paste. One is a plain rim with an inverted profile and a rounded lip. Another has a row of large circular punctations, and the third is a rim with horizontal incised lines; the lip has also been notched. The decorative elements on the latter decorated sherds are also noted in the Middle Caddo ceramic assemblage, and it is possible (perhaps even likely) that these very few non-tempered sandy paste sherds are also Middle Caddo in age. The other two sherds have a clay or silty paste, and are undecorated. All five non-tempered sherds are from vessels fired in a reducing environment; 60 percent were also cooled in the open air. The two rim sherds are $6.2-6.5 \mathrm{~mm}$ in thickness. The body sherds range from 5.6-7.9 $\mathrm{mm}$ in thickness, with a mean thickness of $6.73 \pm 0.78 \mathrm{~mm}$.

\section{Acknowledgments}

Thanks to Lance Trask for revising and preparing the figures for this article.

\section{References Cited}

Anonymous

Memorial: Jack Thomas Hughes (1921-2001). Bulletin of the Texas Archeological Society 73:vii-viii.

Bolton, H. E.

1987 The Hasinais: Southern Caddoans as Seen by the Earliest Europeans, edited by R. M. Magnaghi. University of Oklahoma Press, Norman.

Brown, J. A.

1996 The Spiro Ceremonial Center: The Archaeology of Arkansas Valley Caddoan Culture in Eastern Oklahoma. Memoirs No. 29. Museum of Anthropology, University of Michigan, Ann Arbor.

Bruseth, J. E., and T. K. Perttula

1981 Prehistoric Settlement Patterns at Lake Fork Reservoir. Texas Antiquities Permit Series, Report No. 2. Texas Antiquities Committee and Southern Methodist University, Austin and Dallas.

Clark, J. W and J. E. Ivey

1974 Archaeological and Historical Investigations at Martin Lake, Rusk and Panola Counties, Texas. Research Report 32. Texas Archeological Survey, Austin.

Cliff, M. B. and T. K. Perttula

2002 Results of National Register Investigations Conducted on Site 41PN175, Panola County, Texas. Document No. 010242, PBS\&J, Inc., and Archeological Studies Program, Report No. 32, Texas Department of Transportation, Austin. 
Corbin, J. E. and J. P. Hart

1998 The Washington Square Mound Site: A Middle Caddo Mound Complex in South Central East Texas. Bulletin of the Texas Archeological Society 69:47-78.

Dockall, J. E. and R. C. Fields

2011 National Register Testing of Three Sites in the Sabine Mine's South Hallsville No. 1 Mine-Rusk Permit, Rusk County, Texas. Report of Investigations No. 162. Prewitt and Associates, Inc., Austin.

Dockall, J., S. Katauskas, and R. Fields

2008 National Register Testing of Four Sites in the Sabine Mine's Area M, Harrison County, Texas. Reports of Investigations No. 157. Prewitt and Associates, Inc., Austin.

Dorsey, G. A.

1905 Traditions of the Caddo. Publication No. 41. Carnegie Institution of Washington, Washington, D.C.

Ferring, C. R. and T. K. Perttula

1987 Defining the Provenance of Red-Slipped Pottery from Texas and Oklahoma by Petrographic Methods. Journal of Archaeological Sciences 14:437-456.

Fields, R. C.

1995 Analysis of Native-Made Ceramics. In The Deshazo Site, Nacogdoches County, Texas, Volume 2: Artifacts of Native Manufacture, edited by D. A. Story, pp. 173-232. Studies in Archeology 21. Texas Archeological Research Laboratory, The University of Texas at Austin.

Fields, R. C. and E. F. Gadus (editors)

2012 Archeology of the Nadaco Caddo: The View from the Pine Tree Mound Site (41HS15), Harrison County, Texas. 2 Vols. Reports of Investigations No. 164. Prewitt and Associates, Inc., Austin.

Fischbeck, S. L., J. E. Dockall, E. F. Gadus, and R. C. Fields

2015 National Register Testing of Seven Native American Sites in the South Hallsville No. 1 Mine-Rusk Permit, Area W, Rusk County, Texas. Reports of Investigations No. 178. Prewitt \& Associates, Inc., Austin.

Gadus, E. F.

2013 Twisted Serpents and Fierce Birds: Structural Variation in Caddo Engraved Ceramic Bottle Motifs. Bulletin of the Texas Archeological Society 84:213-245.

Gadus, E. F. and R. C. Fields

2012 Ceramic Artifacts. In Archeology of the Nadaco Caddo: The View from the Pine Tree Mound Site (41HS15), Harrison County, Texas, edited by R. C. Fields and E. F. Gadus, pp. 387-551. 2 Vols. Reports of Investigations No. 164. Prewitt and Associates, Inc., Austin.

Gadus, E. F., R. C. Fields, J. K. McWilliams, J. Dockall, and M. C. Wilder

2006 National Register Testing of Seven Prehistoric Sites in the Sabine Mine's Area Q, Harrison County, Texas. Reports of Investigations, Number 147. Prewitt and Associates, Inc., Austin.

Galan, R. B.

1994 Caddo Mythology: Ethnohistorical and Archaeological Considerations. Mid-America Folklore 22(2):61-67.

Hart, J. P.

1982 An Analysis of the Aboriginal Ceramics from the Washington Square Mound Site, Nacogdoches County, Texas. Master's thesis, Department of Anthropology, Northeast Louisiana University, Monroe.

2014 An Analysis of the Aboriginal Ceramics from the Washington Square Mound Site, Nacogdoches County, Texas. Stephen F. Austin University Press, Nacogdoches. 
Hart, J. P. and T. K. Perttula

2010 The Washington Square Mound Site and a Southeastern Ceremonial Complex Style Zone among the Caddo of Northeastern Texas. Midcontinental Journal of Archaeology 35(2):199-228.

Haskins, P. and M. Walters

2001 Archaeological Investigations of an Oil Well Pad Disturbance at the Tom Moore Site (41PN149), Panola County, Texas. Journal of Northeast Texas Archaeology 14:37-61.

Heartfield, Price, and Greene, Inc.

1988 Data Recovery at 41HS74, Harrison County, Texas. Heartfield, Price, and Greene, Inc., Monroe.

Hoffman, M. P.

1967 Ceramic Pipe Chronology Along the Red River Drainage in Southwestern Arkansas. The Arkansas Archeologist 8:4-14.

Jelks, E. B.

1965 The Archeology of McGee Bend Reservoir, Texas. Ph.D. dissertation, Department of Anthropology, The University of Texas at Austin.

Kelley, D. B.

2006 The Burnitt Site: A Late Caddoan Occupation in the Uplands of the Sabine River Basin of Louisiana. Coastal Environments, Inc., Baton Rouge.

McClurkan, B. B., W. T. Field, and J. N. Woodall

1966 Excavations in Toledo Bend Reservoir, 1964-65. Papers of the Texas Archeological Salvage Project No. 8. Texas Archeological Salvage Project, The University of Texas at Austin.

McKee, A., C. D. Frederick, T. K. Perttula, R. Z. Selden, L. Bush, L. Kemp, B. Gregory, C. Yost, L. S. Cummings, J. R. Ferguson, M. D. Glascock, S. Tomka, L. Cecil, C. Masiello, X. Gao, C. Goodmaster, and V. Beasley, III

2015 Data Recovery Investigations: Murvaul Creek Site (41PN175), Panola County, Texas. Report No. 165. Archeological Studies Program, Environmental Affairs Division, Texas Department of Transportation, Austin.

Middlebrook, T.

1993 Radiocarbon Dates from the Tyson Site (41SY92). Caddoan Archeology Newsletter 3(4):2-8.

1994 An Update of Archaeological Investigations at the Tyson Site (41SY92). Journal of Northeast Texas Archaeology 3:1-36.

1997 The Caddoan Occupation of the Attoyac and Angelina River Basins in the Middle Caddoan Period. Journal of Northeast Texas Archaeology 10:36-40.

Mooney, J.

1896 The Ghost-Dance Religion and the Sioux Outbreak of 1890. Part 2 of the Fourteenth Annual Report. Bureau of Ethnology, Smithsonian Institution, Washington, D.C.

Perttula, T. K.

2000 Stylistic and Functional Analyses of Ceramic Vessels from Mortuary Features at a $15^{\text {th }}$ and $16^{\text {th }}$ Century Caddo Site in Northeast Texas. Midcontinental Journal of Archaeology 25(1):101-151.

2001 The Analysis of Caddoan Ceramics from Four Sites in Rusk County, Texas. In NRHP Eligibility Testing (41RK107, 41RK240, 41RK242, 41RK243, 41RK276, and 41RK286) and Additional Testing (41RK243) Investigations within the Oak Hill DIII Mine, Permit No. 46, Rusk County, Texas, by D. L. Sherman, pp. 95-115. Document No. 000237. PBS\&J, Inc., Austin.

2009 (with contributions by B. Nelson and M. Walters) Analysis of the Caddo Archeological Materials from the 1985 Texas Archeological Society Field School at the Washington Square Mound Site, Nacogdoches County, Texas. Bulletin of the Texas Archeological Society 80:145-193. 
2013 Caddo Ceramics in East Texas. Bulletin of the Texas Archeological Society 84:181-212.

2014 The Caddo Archaeology of the Musgano Site (41RK19) in the Sabine River Basin of East Texas. Special Publication No. 28. Friends of Northeast Texas Archaeology, Pittsburg and Austin.

2015 Aboriginal Ceramic Vessel Sherds and Pipe Sherds from the Murvaul Creek Site (41PN175). In Data Recovery Investigations: Murvaul Creek Site (41PN175), Panola County, Texas, by A. McKee, C. D. Frederick, T. K. Perttula, R. Z. Selden, L. Bush, L. Kemp, B. Gregory, C. Yost, L. S. Cummings, J. R. Ferguson, M. D. Glascock, S. Tomka, L. Cecil, C. Masiello, X. Gao, C. Goodmaster, and V. Beasley, III, pp. 107-180. Report No. 165. Archeological Studies Program, Environmental Affairs Division, Texas Department of Transportation, Austin.

Perttula, T. K. (editor)

2002 Archeological Investigations at the Proposed Lake Naconiche, Nacogdoches County, Texas. 2 Vols. Report of Investigations No. 42. Archeological and Environmental Consultants, Austin.

2008 Lake Naconiche Archeology, Nacogdoches County, Texas: Results of the Data Recovery Excavations at Five Prehistoric Archeological Sites. 2 Vols. Report of Investigations No. 60. Archeological \& Environmental Consultants, LLC, Austin.

Perttula, T. K. and B. Nelson

2003 The Nawi haia ina Site (41RK170): Archeological Investigations in the City of Henderson's Southside Wastewater Treatment Plant, Rusk County, Texas. Report of Investigations No. 51. Archeological \& Environmental Consultants, LLC, Austin and Pittsburg.

Perttula, T. K., M. Walters, R. Cast, B. Gonzalez, and B. Nelson

2007 Documentation of Funerary Offerings from a Prehistoric Caddo Burial at Site 41WD244, Wood County, Texas. Caddo Nation of Oklahoma and Archeological \& Environmental Consultants, LLC, Binger and Austin.

Perttula, T. K., M. Walters, B. Nelson, B. Gonzalez, and R. Cast, with a contribution by R. G. Franciscus 2010 Documentation of Associated and Unassociated Caddo Funerary Objects in the Stephen F. Austin State University Collections, Nacogdoches, Texas. Stephen F. Austin State University Press, Nacogdoches.

Reese-Taylor, K., A. Bates, and T. K. Perttula

2004 Analysis of Pastes, Temper, Vessel Forms, and Manufacturing Attributes in the Oak Hill Village Sherd Assemblage. In The Oak Hill Village (41RK214), Rusk County, Texas, by R. Rogers and T. K. Perttula, pp. 273-285. Document No. 030083. PBS\&J, Inc., Austin.

Rice, P. M.

1987 Pottery Analysis: A Sourcebook. University of Chicago Press, Chicago.

1996 Recent Ceramic Analysis: 1. Function, Style, and Origins. Journal of Archaeological Research 4(2):133-163.

Rogers, R. and T. K. Perttula

2004 The Oak Hill Village (41RK214), Rusk County, Texas. Document No. 030083. PBS\&J, Inc., Austin.

Rogers, R., M. A. Nash, and T. K. Perttula

2001 Excavations at the Herman Bellew Site (41RK222), Rusk County, Texas. Document No. 000021. PBS\&J, Inc., Austin.

Schambach, F. F.

2002 The Grandview Archeological Project: The Arkansas Archeological Survey/Arkansas Archeological Society's 2002 Field Season at the Grandview Prairie Wildlife Management Area, Columbus, Arkansas. Field Notes (Arkansas Archeological Society) 308:3-8. 
Schambach, F. F. and J. E. Miller

1984 A Description and Analysis of the Ceramics. In Cedar Grove: An Interdisciplinary Investigation of a Late Caddo Farmstead in the Red River Valley, edited by N. L. Trubowitz, pp. 109-170. Research Series No. 23. Arkansas Archeological Survey, Fayetteville.

Schmidly, D. J.

2002 Texas Natural History: A Century of Change. Texas Tech University Press, Lubbock.

Selden, R. Z, Jr. and T. K. Perttula

2013 Radiocarbon Trends and the East Texas Caddo Tradition (ca. A.D. 800-1680). Southeastern Archaeology 32(1):85-96.

Skibo, J. M.

1992 Pottery Function: A Use-Alteration Perspective. Plenum Press, New York.

Suhm, D. A. and E. B. Jelks (editors)

1962 Handbook of Texas Archeology: Type Descriptions. Special Publication No. 1, Texas Archeological Society, and Bulletin No. 4, Texas Memorial Museum, Austin.

Swanton, J.R.

1942 Source Material on the History and Ethnology of the Caddo Indians. Bulletin 132. Bureau of American Ethnology, Smithsonian Institution, Washington, D.C.

Teltser, P. A.

1993 An Analytic Strategy for Studying Assemblage-Scale Ceramic Variation: A Case Study from Southeast Missouri. American Antiquity 58(3):530-543.

Turner, R. L., Jr., J. E. Smith II, T. K. Perttula, B. Nelson, M. Walters, and B. Gonzalez

2003 The Harold Williams Site (41CP10) and the Texas Archeological Society Field School of 1967. Bulletin of the Texas Archeological Society 73:1-68.

Walters, M.

1997 The Langford Site (41SM197), Smith County, Texas. Journal of Northeast Texas Archaeology 9:38-41.

2003 The Wolf Site (41SM195), Smith County, Texas. Journal of Northeast Texas Archaeology 18:1-21.

2004 41SM195A, the Browning Site. Journal of Northeast Texas Archaeology 20:1-42.

2006 The Lake Clear (41SM243) Site and Crotalus horridus atricaudatus. Caddoan Archeology Journal 15:5-41.

2008 Life on Jackson Creek, Smith County, Texas: Archeological Investigations of a $14^{\text {th }}$ Century Caddo Domicile at the Leaning Rock Site (41SM325). Caddo Archeology Journal 17:1-114.

Walters, M., P. Haskins, D. H. Jurney, S. E. Goldborer, and T. K. Perttula

1998 Archaeological Investigations at the Redwine Site (41SM193), Smith County, Texas. Journal of Northeast Texas Archaeology 11:1-38.

Wilson, D. E.

2003 Analysis of the Human Remains from Burials 1 and 2 from the Nawi haia ina site (41RK170). In The Nawi haia ina Site (41RK170): Archeological Investigations in the City of Henderson's Southside Wastewater Treatment Plant, Rusk County, Texas, by T. K. Perttula and B. Nelson, p. 122-132. Report of Investigations No. 51. Archeological \& Environmental Consultants, LLC, Austin and Pittsburg.

Woodall, J. N.

1969 Archeological Excavations in the Toledo Bend Reservoir, 1966. Contributions in Anthropology No. 3. Department of Anthropology, Southern Methodist University, Dallas. 